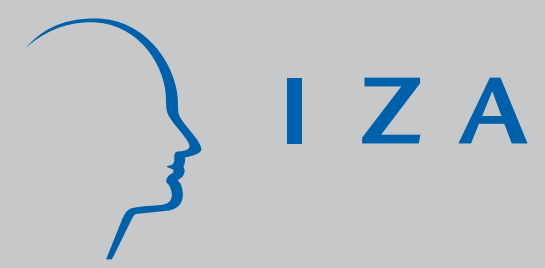

IZA DP No. 8581

Choosing to Be Trained: Do Behavioral Traits Matter?

Utteeyo Dasgupta

Lata Gangadharan

Pushkar Maitra

Subha Mani

Samyukta Subramanian

October 2014 


\title{
Choosing to Be Trained: Do Behavioral Traits Matter?
}

Utteeyo Dasgupta

Wagner College

Lata Gangadharan

Monash University

Pushkar Maitra

Monash University

\author{
Subha Mani
}

CIPS, Fordham University,

PSC, University of Pennsylvania and IZA

\section{Samyukta Subramanian}

Pratham, India

\section{Discussion Paper No. 8581 \\ October 2014}

IZA

P.O. Box 7240

53072 Bonn

Germany

Phone: +49-228-3894-0

Fax: +49-228-3894-180

E-mail: iza@iza.org

\begin{abstract}
Any opinions expressed here are those of the author(s) and not those of IZA. Research published in this series may include views on policy, but the institute itself takes no institutional policy positions. The IZA research network is committed to the IZA Guiding Principles of Research Integrity.

The Institute for the Study of Labor (IZA) in Bonn is a local and virtual international research center and a place of communication between science, politics and business. IZA is an independent nonprofit organization supported by Deutsche Post Foundation. The center is associated with the University of Bonn and offers a stimulating research environment through its international network, workshops and conferences, data service, project support, research visits and doctoral program. IZA engages in (i) original and internationally competitive research in all fields of labor economics, (ii) development of policy concepts, and (iii) dissemination of research results and concepts to the interested public.
\end{abstract}

IZA Discussion Papers often represent preliminary work and are circulated to encourage discussion. Citation of such a paper should account for its provisional character. A revised version may be available directly from the author. 


\section{ABSTRACT \\ Choosing to Be Trained: Do Behavioral Traits Matter?*}

In this paper, we examine the determinants of self-selection into a vocational training program in India. To do this we combine data from an artefactual field experiment with survey data collected from the targeted community. We find that applicants and non-applicants differ in terms of socio-economic characteristics (measured using a survey), as well as selected behavioral traits (elicited using an artefactual field experiment). Even after controlling for a range of socio-economic characteristics, we find that individuals who have higher tolerance for risk, and are more competitive, are more likely to apply to the training program. This suggests that focusing only on the socio-economic and demographic characteristics might not be sufficient to fully explain selection into the program. Participants' behavioral traits are also crucial in influencing take up rates in such programs. Our results suggest that as a methodology, there is valuable information to be gained by dissecting the black box of unobservables using data on behavioral traits.

JEL Classification: J24, C93, C81

Keywords: $\quad$ selection, artefactual field experiment, behavioral traits, household survey, training program

Corresponding author:

Subha Mani

Fordham University

Department of Economics

441 East Fordham Road

Dealy Hall, E 520

Bronx, New York 10458

USA

E-mail: smani@fordham.edu

\footnotetext{
* We would like to thank Stefan Dercon, Ben Greiner, Glenn Harrison, John Hoddinott, David Huffman, Tarun Jain, Pramila Krishnan, Aprajit Mahajan, David Reiley, Shailendra Sharma, John Strauss, Robert Thornton, Marie Claire Villeval, two anonymous referees, an associate editor, and the co-editor of this journal, seminar participants at Vassar College, Calcutta University, Indian School of Business, Queensland University of Technology, participants at the PACDEV Conference, International Atlantic Economic Society Conference, the DRU workshop at Monash University, the Australian Development Economics Workshop, the ESA International Meetings, the India Development Workshop at UNSW, and the Nordic Conference for Development Economics for their comments and suggestions. Shelly Gautam, Inderjeet Saggu, Sarah Scarcelli and Raghav Shrivastav provided excellent research assistance. Funding was provided by Monash University, Australia and Fordham University, USA. We are especially grateful to the staff of Satya and Pratham for their outstanding work in managing the implementation of the vocational training program. The usual caveat applies.
} 


\section{Introduction}

Worldwide recession along with increasing unemployment has renewed interest in trainingprograms that help workers accumulate additional skills to obtain new jobs or retain current ones. The economic benefits of participating in such training programs are substantial in developing countries. ${ }^{1}$ However, these programs can help attenuate unemployment only if the targeted individuals volunteer to participate in the program. If instead, they refrain from participating in these specialized avenues of skill building, then increasing the supply of training schools and programs as a policy achieves little towards the final goal of improving labor market outcomes and welfare. For a policy-maker then, there is a case not just for promoting labor market training programs, but also to target them better to reap maximum welfare gains through increased participation. To achieve this, it is crucial to identify the selection process that identifies the factors influencing participation into the program.

Our goal in this paper is to focus on the participation decision, i.e., to determine whether individuals who apply to a training program, and those who do not, differ systematically along measured behavioral traits and socio-economic characteristics. ${ }^{2}$ Identifying these traits can help us design and promote skill building programs more effectively in the future.

Self-selection has been previously studied in different contexts such as entrepreneurship (Cramer et al. (2002) in Netherlands; Bauernschuster et al. (2010) in Germany), participation into a labor market training program in the US (Heckman and Smith (2004)), a school incentive program in India (Barnhardt et al. (2009)), a microfinance, soft skills and entrepreneurship program in Uganda (Bandiera et al. (2012)), and a migration program for Tongans (McKenzie et al. (2010)). However, all these papers have relied only on the use of survey data to estimate

\footnotetext{
${ }^{1}$ Attanasio et al. (2011), Maitra and Mani (2013), Blattman et al. (2014) respectively find that training increases paid employment and/or self-employment opportunities for women in Colombia, India, and Uganda respectively.

2 The training program is discussed in Section 2.1 of this paper. Maitra and Mani (2013) show that training increased the probability of being employed in casual or full-time work by 6.4 percentage points, and the probability of being self-employed by 4 percentage points.
} 
the participation or selection equation, leaving out possible sources of differences arising due to variation in behavioral characteristics between participants and non-participants. We aim to fill this crucial gap by examining the differences between applicants and non-applicants in a labormarket training program in terms of both behavioral traits and socio-economic characteristics. We do this by combining data from a unique artefactual field experiment and responses from primary surveys. ${ }^{3}$

The training program we examine was widely advertised to women between the ages of 18 and 39 years, having 5 or more grades of schooling, and residing in selected resettlement colonies (or slums) in New Delhi, India. Participants in our experiment consisted of a randomly selected pool of applicants (who applied to the training program), and non-applicants (those who chose not to apply in spite of receiving the advertisement). The artefactual field experiment was designed to elicit unobservable behavioral characteristics such as risk attitudes, confidence level, and attitudes towards competition. We also administered a detailed household survey, which allowed us to examine household characteristics that can further influence the selfselection.

Our results show that the probability of applying to the training program can vary in terms of both socio-economic and behavioral characteristics. We find that younger women, with prior experience in stitching and tailoring, not belonging to the backward caste (a description used by the Government of India to identify socially and economically disadvantaged groups), belonging to relatively richer households, and those with a higher dependency ratio (defined as the ratio of number of children aged less than 5 to the number of adult women in the household), have a significantly higher probability of applying to the training program. Further, the results from our artefactual field experiment reveal that women with greater preference for

\footnotetext{
${ }^{3}$ According to the taxonomy developed by Harrison and List (2004), the experiment reported in this paper would be termed an artefactual field experiment. That is, we examine behaviour using similar rules and procedures as in a laboratory but employ a non-standard subject pool. Using a recent classification system developed by Charness et al. (2013), the experiment could also be referred to as an extra-lab experiment.
} 
risk and competition are significantly more likely to apply to the training program. In contrast to what has been done previously in the literature, this suggests that focusing only on the socioeconomic and demographic characteristics might not be sufficient to fully explain selection into the program. Participants' behavioral traits are important determinants of self-selection into labor market training programs and can influence take up rates in such programs.

While individuals can vary along many behavioral dimensions, we chose to investigate three important dimensions that can critically influence the choice of selecting/applying into the program. The first source is risk preference. It is well documented that risk attitudes affect important life choices including occupational choices (Castillo et al. (2010)), investment in higher education (Belzil and Leonardi (2009), Chen (2003)), and technology adoption (Liu (2008)) Additionally, in developing countries incomplete financial markets fail to smooth economic risks, and institutional hurdles make any investment fraught with uncertainty. As a result, only individuals with a higher tolerance for risk might be willing to engage in any investment activity. Joining a skill accumulation program is an investment activity that involves considerable time and monetary costs with often delayed and uncertain benefits. Consequently, one would expect that, risk attitudes might play a role in the decision to participate in the training program.

Second, we examine whether competitiveness influences the participation decision into the training program. Previous literature suggests that differences in competitiveness influence wage differences, educational choices, workplace choices, and influence the evolution of gender differences (Niederle and Vesterlund (2007), Gneezy et al. (2009), Andersen et al. (2010), Flory et al. (2010), Buser et al. (2012)). This leads us to hypothesize that differences in competitiveness possibly impact the decision to apply for an income enhancing training program as well.

Third, confidence is claimed to have a significant impact on labor market outcomes (Koszegi (2006), Bénabou and Tirole (2002)), although credible empirical evidence on the effect of confidence on labor market outcomes is rare due to the difficulty in measuring and 
obtaining data on confidence. It has been pointed out that the level of confidence can affect wage rates (Fang and Moscarini (2005)), performance in financial markets (Biais et al. (2005)) entrepreneurial behavior (Cooper et al. (1988), Camerer and Lovallo (1999), Bernardo and Welch (2001), Koellinger et al. (2007)), and can explain the persistence of intergenerational inequality in income and education (Filippin and Paccagnella (2009)).

The three behavioral traits we have identified are obviously important for those interested in entrepreneurship and self-employment opportunities. These traits however, are also relevant for those interested in seeking wage employment. Job-seekers are typically exposed to risk related to the probability of finding a job, and face the uncertainty of receiving higher future wages when employed (see Bonin et al. (2007) and Pfeifer (2011) for a discussion on the impact of risk preferences on wages in salaried employment). More confident and more competitive individuals might be more successful in obtaining jobs and receiving success (promotion/wage increases) in these jobs. So it is important to examine and understand how these specific traits influence selection into training programs that can improve labor market outcomes (both wage and self employment).

The rest of the paper is organized as follows. Section 2 includes a description of the training program, the subject pool, and the experimental design. Descriptive statistics and regression results are presented in Section 3. Concluding remarks follow in Section 4.

\section{Methodology}

\subsection{Background: The Training Program}

The data used in this paper were collected as a part of a baseline survey and an artefactual field experiment administered to a pool of applicants and non-applicants of a subsidized training program in stitching and tailoring services. This program was implemented jointly by two nongovernmental organizations (NGOs) - Pratham Delhi Education Initiative (Pratham) and Social Awakening Through Youth Action (SATYA) - and was conducted between August 2010 and January 2011. The survey and the artefactual field experiment were both administered prior to 
the beginning of the program. ${ }^{4}$

The stitching and tailoring program required a time commitment of 10 hours a week and taught participants to stitch clothes for women, men, and children. In June 2010 all program related information was widely advertised to every household in the disadvantaged areas (slums/resettlement colonies) of South and North Shahdara in New Delhi, India. The advertisement did not focus on any specific sub-group in the population, and was distributed to every household in the target area to ensure maximum outreach for the program. As a result, all women (eligible and ineligible, residing in the same household) received the information about the training program. Further, the description of the scope of the training program was kept general enough to encourage all eligible women to apply, and avoid attracting women with any specific characteristics that could have biased our results. ${ }^{5}$ The English version of the advertisement pamphlet is presented in Figure 1 (originally in Hindi). The eligibility criteria in the pamphlet specified women had to be between the ages of 18 and 39, with at least five or more completed grades of schooling and living in the targeted area. SATYA and Pratham employees held joint information sessions, where interested women had the opportunity to meet with representatives from the two NGOs to discuss and clarify questions about the program. The sessions, along with the advertisement pamphlets specified that training would be provided by well-qualified and reputable staff, using modern techniques of stitching and tailoring; new sewing machines and other related resources would also be provided on site. The participants were further told that they would receive a certificate at the end of the program. Application forms were made available for distribution at these information sessions and all women were asked to take the application forms back home, discuss this opportunity with their family, and

\footnotetext{
${ }^{4}$ In preparation for the training program, a pre-baseline census was used to generate basic information on all households located in all target areas of the South Shahdara region in New Delhi, India in May 2010. The census used a standard "house listing" method to list details on the names of all household members and collected information on their age and highest grade of schooling. The "house listing"/census survey was conducted by Pratham.

${ }^{5}$ For example, as an anonymous referee correctly points out that if we had mentioned setting up own business only as a post-training outcome, we might have ended up attracting less risk averse women.
} 
then return the completed forms back to the NGOs within the deadline.

\subsection{The Subject Pool for the Artefactual Field Experiment}

While the training program was open to all eligible women residing in both the South and North Shahdara regions of New Delhi, the artefactual field experiment was conducted only in South Shahdara because of operational considerations (field specific and funding constraints). A total of 222 women residing in South Shahdara (153 of whom were applicants and 69 were nonapplicants) participated in the artefactual field experiment, which was conducted in July $2010 .^{6}$ At that time no one knew of the eventual treatment status of the applicants to the training program since the lottery had not been conducted, thereby ruling out the possibility of the treatment status influencing the decision to participate in the artefactual experiment. In addition, at the time of recruitment for the artefactual field experiment, all potential participants (particularly the applicants) were informed that outcomes in the artefactual field experiment would have no bearing on their selection into the training program.

\subsubsection{Sampling}

Since only a small proportion (5.5 percent) of the eligible women applied to the program, inviting a random sample of eligible women from the population to the artefactual field experiment might have resulted in a subject pool with inadequate number of applicants. We used a choice based sampling strategy and oversampled the applicants to rule out that possibility. As a result of oversampling the applicants, the parameter estimates from a standard probit regression (for applicant status) give us coefficients that represent the sample but not the population and may therefore be biased. To correct for this, we adopt a Weighted Endogenous Maximum Likelihood estimation strategy. This is discussed in sections 2.3 and 3.2.

Due to time and funding constraints we first decided on the maximum number of

\footnotetext{
${ }^{6} 67 \%$ of the final sample of applicants who participated in the artefactual field experiment were ultimately randomly assigned to the treatment group and the remaining to the control group. Since the information about their treatment status was not known to any of the stake holders (the applicants, the researchers, and the NGOs) at the time of the artefactual field experiment and the survey, the regression results presented in Tables 3 and 4 do not take into account the ultimate treatment status.
} 
invitations (300) for the 12 experimental sessions. Next, we used the addresses of the applicants and randomly drew 200 women, who were then invited to participate in the artefactual field experiment. For the non-applicants, we followed a similar strategy and randomly invited 100 women who satisfied the eligibility criterion (5 or more grades of schooling, between the ages of 18 and 39 years, and residing in South Shahdara). 153 applicants out of the 200 invited, and 69 non-applicants out of the 100 invited showed up to participate in the artefactual field experiment. ${ }^{7}$ A more detailed discussion of this issue is presented in section 2.3.

Subjects who participated in the artefactual field experiment were also requested to complete a household survey that collected detailed information on household demographic characteristics, schooling outcomes, assets, employment, and quality of life. Due to the length of the household survey, it was not possible to administer the survey during the experiment. The survey was therefore conducted at the participants' homes at a later date but before the women knew their treatment status. We were unable to collect survey data from 18 (7 applicants and 11 non-applicants) of the 222 women who participated in the experiment - either they could not be traced or they did not want to participate in the survey. Selection-related concerns arising from non-response in the household survey are further discussed in section 2.3.

Our final sample for which we have both data from the artefactual field experiment and the household survey consists of 204 women - 146 applicants to the training program and 58 non-applicants. See Table 1 for a complete distribution of applicants and non-applicants at different stages. We conducted 12 sessions with 16 - 20 subjects in each session. Each session lasted approximately 2 hours and each subject participated in only one session. The average payment received from participation was Rs. $203{ }^{8}$

\footnotetext{
${ }^{7}$ The difference between the two groups of participants (76.5\% of the invited applicants and $69 \%$ of the invited non-applicants participated) is not statistically significant ( $p$-value $=0.16$ using a two-sided t-test). ${ }^{8}$ The official minimum wages for unskilled workers in Delhi was Rs 203 per day at the time of running these experiments (in 2010). However, the minimum wage legislations are rarely imposed in India, and most women in our sample would be receiving less than this stipulated amount. Cardenas and Carpenter (2008) in their survey of field experiments in developing countries argue that paying on average one to two days wage for a half-day session creates the necessary salience for participants in the field (page
} 


\subsubsection{Recruitment process}

Two weeks after the deadline for applying to the program, 200 women from the pool of all eligible applicants and 100 women from the pool of eligible non-applicants to the vocational training program were randomly selected and invited to participate in one randomly chosen session of the artefactual field experiment. Consequently, the group composition was randomly determined. Although we did not collect data on how many other group members each participant knew, given the high density of population in South Shahdara it is unlikely that participants knew many of the other participants in the session they participated in. The sessions were conducted at the South Shahdara Pratham office, a prominent and convenient location for all South Shahdara residents. Pratham employees were hired as recruiters for the artefactual field experiment. The team of recruiters had no information about the experiment and were instructed to say the following to both applicants and non-applicants: “Greetings, you are invited to participate in a game at Pratham's South Shahdara office (give the specific address and directions to the office). You will receive a fixed payment of Rs 150 for showing up on time for the games. In addition, you will be able to earn more money by participating in these games. If you are willing to participate in these games and or have further questions about the games, please visit our office at the designated date and time”. As explained earlier, it was also stressed during the time of the recruitment that participation in the artefactual experiment will have no influence on the placement into the treatment group of the training program.

\subsection{Exploring Sample Bias}

The research question we aim to address, and the sampling techniques we use, can lead to three potential sources of sample selection: 1) Not all women who were invited to participate in the experiment actually showed up to participate. 2) Some women who participated in the experiment did not participate in the household survey. 3) The proportion of applicants and non-

331). For a two-hour session that we conducted, a day's worth of wages satisfies this criterion. The exchange rate at the time of running these experiments was \$1 (US) = Rs 46. 
applicants in our final sample is different from the population proportions. We rule out all three of these sample selection concerns below.

First, to rule out bias arising from non-response/selection into the artefactual field experiment, we show that (i) women who were invited and participated in the experiment are no different to the women who were invited and did not participate in the artefactual field experiment; and (ii) that applicants and non-applicants who participated in the experiment are representative of the applicant and non-applicant population in South Shahdara. To address point (i) we compare age and completed grades of schooling of women who were invited and showed-up with that of women who were invited but did not show-up, separately for the applicants and non-applicants. We are able to make these comparisons using information on two demographic characteristics - age and completed grades of schooling - that were collected as part of the pre-baseline census of eligibility in the region. These comparisons are reported in Panel A, Table A1 in Appendix 1, columns 3 and 6. We find no significant difference in age and completed grades of schooling between subjects who were invited and showed up, and subjects who were invited but did not show-up in the two groups: applicants and non-applicants. To address point (ii) we compare the average age and completed grades of schooling of all applicants and non-applicants in the census who did not participate in the artefactual field experiment with that of the applicants and non-applicants who participated in the artefactual field experiment. The results presented in columns 3 and 6, Panel B of Table A1 shows that both the applicant and the non-applicant sample is representative of the respective population along these two demographic characteristics.

Second, we need to ensure that non-response in the survey (after participating in the experiment) is not systematically related to observed behavioral characteristics, leading to a potential bias in our results. To do this, we compare the behavioral characteristics of subjects who participated in the artefactual field experiment and completed the survey, with subjects who only participated in the artefactual field experiment but did not complete the survey (see Table A2 in Appendix 1). This Table shows that there are no significant differences between 
these two groups of participants. We also estimate a probit regression where the dependent variable (non-response) is a dummy that takes a value of 1 if household survey data is missing and 0 otherwise. The explanatory variables in this regression include the set of behavioral traits included in specification 3 in Table 3 (see below) and the interaction of these variables with applicant status. The results are presented in Table A3 in Appendix 1. None of the variables included in the set of explanatory variables (interacted or not) are statistically significant and the interaction terms are also not jointly statistically significant. This implies that non-response is not systematically related to behavioral differences between applicants and non-applicants. Additionally, we compare the age and completed grades of schooling available for the two groups (available from the pre-baseline census) and do not find a significant difference in these two characteristics between survey responders and non-responders in the applicant and nonapplicant groups (see columns 3 and 6, Panel C, Table A1). ${ }^{9}$

Finally, the results presented in section 3 could have been biased because of the fact that the sample proportion of the applicants and non-applications were not representative of the population proportions. Any concern that the sample is skewed in favor of the applicants and does not represent the true population is addressed by using the weighted endogenous sampling maximum likelihood (WESML) estimation technique proposed by Manski and Lerman (1977). See Section 3.2 for more details.

In summary, our analysis allows us to rule out any systematic bias in the sample and concludes that our subject pool is representative of the population. ${ }^{10}$

\footnotetext{
${ }^{9}$ To improve the power of the tests presented in Panels A, B, and C in Table A1, we conducted two additional comparisons. First, Panel D in Table A1 shows that there is no statistically significant difference in age and completed grades of schooling between the 222 women who were invited and participated in the artefactual field experiment and the 78 who were invited but did not participate. Second, Panel E of Table A1 shows that there is no statistically significant difference in the completed grades of schooling between the 204 women who participated in both the artefactual field experiment and the household survey and the 96 who were invited but did not participate in either. The average age of women in the latter group is however marginally greater than that in the former. This is not surprising as a greater proportion of women who are included in the sample in column 1 of Panel E belong to the set of applicants who are younger than the non-applicants (as we observe in Table 2).

${ }^{10}$ An alternative sampling strategy (suggested by an anonymous referee) would have been to conduct the artefactual field experiment and the survey before the training program was advertised. While this
} 


\subsection{Design}

Each subject participated in two games (the games are similar to those reported in Gneezy et al. (2009)). The first game was designed to evaluate subjects' attitudes towards risk (investment game). Each subject was endowed with Rs 50 and had the option of allocating any portion of her endowment to a risky asset that had a 50\% chance of quadrupling the amount invested. The invested amount could also be lost with a 50\% probability. The subject retained any amount that she chose not to invest. If the investment game was chosen for payment purposes, each subject tossed a coin that determined whether her investment succeeded or not.

The second game was designed to investigate the inherent competitiveness of subjects (competition game). Each subject participated in a real-effort task, which consisted of filling up $1.5 \mathrm{fl}$ oz. zip lock bags in a minute with kidney beans (locally known as rajma). Prior to the task a subject had to privately choose one of two methods of compensation. She could choose a piece-rate compensation method, which depended solely on her own performance, and she would receive Rs 4 for each correctly filled bag. Alternatively, she could choose a competitionrate compensation method where her earnings would depend on how she performed relative to another randomly chosen subject in the same session. A subject received Rs 16 per bag if she filled equal number of bags or more bags than her matched opponent. If she filled fewer bags than her opponent, she received nothing. If the competition game was chosen for payment purposes and if the participant had chosen the competition rate payment method, she was matched with one other person in the session for payment. The matching was done as follows.

approach could potentially help participants further disassociate the decisions in the experiment with selection into the program, it could create other critical problems. Specifically we would have then faced considerable sampling issues because at the time of the artefactual field experiment we would not know whether a particular participant would ultimately apply to the program or not. Since only a very small proportion of the eligible women actually applied to the program, inviting a random sample of eligible women from the population $(\mathrm{N}=4417)$ to the artefactual field experiment might not have provided us with a subject pool with adequate number of applicants. This would potentially make this current study less robust and perhaps not even feasible and also lead to an ineffective evaluation of the training program conducted. We do note however that this is an interesting idea and a future research project could explore whether in such an environment, the timing of the artefactual field experiment would matter. 
The subject drew a chit from a box containing the IDs of the other participants in the session. Her performance was matched to that of the person whose ID was drawn. The matched participant's payoff remained unaffected. The participants were informed of this process beforehand and assured that all parts of the decision-making will be in private.

Our design in this game was similar to Gneezy et al. (2009) and Cameron et al. (2013) and was necessitated due to cognitive characteristics of our subjects and time constraints in our field environment. Since the participants did not compete against a fixed past performance of others as in the Niederle and Vesterlund (2007) study, there was a possibility that the session composition could affect the decision to compete. However, as explained above, the composition of all sessions was randomly determined. Session composition and the expectations of subjects about who would compete should be therefore on an average similar across sessions. ${ }^{11}$

When choosing their compensation method, the subjects were asked to guess their own performance in the game. More specifically, each subject was asked to provide an estimate of the number of bags she expected to fill in the real-effort task, and also her own performancebased relative rank. We use participant's guesses about her performance in the real effort task to construct three different measures of confidence: (a) an absolute measure of confidence (the subject's estimate about the number of bags she would be able to fill in one minute); (b) a relative measure of confidence (the subject's estimate about her relative standing (rank) vis-à-

\footnotetext{
${ }^{11}$ We conducted several additional statistical tests to explore if there are systematic session level differences in the proportion of women choosing to compete. A chi-square test on equality of choices between sessions indicates no significant relationship between the type of compensation scheme chosen and the session (available on request from the authors) except in one specific session. We re-estimated the preferred specification reported in the paper excluding data from this particular session (thereby excluding 22 subjects), and obtain similar results. In addition, we decompose the variation in the choice of the competition-rate payment scheme in the competition game and find that $95 \%$ of the variation in the choice of the competition-rate payment scheme in the competition game comes from within session variation and only $5 \%$ of the variation in choices is explained by variation across sessions, i.e., substantial homogeneity in choices across sessions and substantial heterogeneity in choices within each session. We also ran a regression where the dependent variable is choice of competitive wage scheme in the competition game. We regress this variable on the set of session dummies. The overall test that the assignment to the session does not affect the choice of competitive wage scheme in the competition game cannot be rejected $(p$-value $=0.59)$.
} 
vis other participants in the session); and (c) confidence ratio, (the ratio of the number of bags the subject expects to fill to the number of bags she actually fills). ${ }^{12}$

In each session, only one of the games was chosen for payment purposes. For the realeffort task in the experiment we wanted to avoid a task that was very familiar to a particular sub-section of our subjects as that could possibly bias their expectations about their performance in the game (See Gneezy et al. (2009) for a discussion). At the same time, we needed to choose a task that was feasible for our subject population, which ruled out many of the familiar experimental tasks such as computing sums, or word tasks since our participants (and indeed the population they are drawn from) are weak in these skills. Kidney beans comprise a staple diet in the region; women are used to handling the beans regularly - they take them out in bowls, clean and cook them, and all our participants are likely to be equally familiar with this particular task.

No communication was allowed during the session. The instructions were read out in Hindi. ${ }^{13}$ We also displayed visual descriptions of the tasks while reading out the instructions, (see Figures A1 and A2 in Appendix 2). To enhance comprehension and minimize anchoringbias, the instructions contained examples different from the ones displayed in the charts. In addition, to ensure comprehension of the game, each subject was asked a few questions prior to making choices in each game. ${ }^{14}$ While the same female experimenter read the instructions out

\footnotetext{
${ }^{12}$ We define this ratio to be 1 , if the participant has realistic expectations about her performance, greater than 1 if she is overconfident, and less than 1 if she is under-confident.

${ }^{13}$ The instructions were first prepared in English, and then translated into Hindi by a native Hindi speaker. The English and Hindi versions were compared and verified for consistency by a person fluent in both Hindi and English. The English version of the instructions are presented in Appendix 2.

${ }^{14}$ These questions were not used to screen subjects. Instead, they were used to gauge the subject's level of comprehension related to the games. All subjects were allowed to continue irrespective of whether they correctly answered these questions in their first attempt. However, if the subject could not answer the question or answered it incorrectly, the experimenter explained the problem to the subject in more detail and helped the subject to work out the answer to the questions. The purpose of this exercise was to minimize noise from lack of comprehension given our "non-standard" subject pool (the average subject has only nine completed grades of schooling). 12 subjects across all our sessions initially had problems comprehending the instructions (5 in the investment game, 4 in the competition game, and 3 in both games). Eliminating these 12 subjects from our regression analysis does not change our results. These are available from the authors on request.
} 
aloud in every session, the questions were administered by two or three experimenters, depending on availability. ${ }^{15}$

Several of our subjects, despite having completed 5 or more grades of schooling, had poor reading and writing skills. ${ }^{16}$ The experimenters were therefore required to be actively involved in administering the questions and noting down the responses. Such a protocol could reduce the social distance between the subject and the experimenter, and potentially create scrutiny effects. Our main interest lies in the differences in the responses of applicants and nonapplicants, and as long as any one of the groups is not systematically more affected by the scrutiny effect, any potential bias arising from the scrutiny effect will be differenced out. The fact that the decisions taken in the games were not hypothetical and influenced by non-trivial monetary amounts, reinforces the contention that subject choices can be viewed as real investment decisions, and are minimally affected by any lack of social distance. We think that our method is particularly relevant for field experiments run in developing countries where participating subjects might not have sufficient reading and writing skills.

The experimental protocol remained the same in every session: the experimenter read the general instructions aloud first; she then read out the instructions for the investment game; subjects made allocation decisions privately for the investment game; the experimenter read out the instructions for the competition game, and then administered questions about the choice of the compensation method and the confidence level of subjects in private. The real effort task was conducted last, and finally a coin was tossed to decide the game that would be used for payment. At the conclusion of the experiment each subject was called and paid their earnings in cash privately. ${ }^{17}$

\footnotetext{
${ }^{15}$ An analysis of responses indicates that there are no differences depending on the gender of the experimenter administering the questions.

${ }^{16}$ Even with recent advances in overall educational attainment in India, as of 2005 half the children enrolled in grade five could not read (and write) grade two level text (see Pratham (2006)). Levels of educational attainment were only worse when our participant pool attended school.

${ }_{17}$ Note that in the competition game the subjects chose their preferred payment scheme after the instructions had been read out and after it was clearly demonstrated to them what we mean by a correctly
} 
The games were always run in the same order (i.e., the investment game, followed by the competition game), no feedback was provided to the subjects in between the two games and subjects were paid on the basis of the outcomes in one of the two tasks, randomly determined after all participants had finished participating in both games. The only task that a subject received any feedback for was the one for which she was paid. Due to our chosen experimental design we cannot explicitly test for order effects; however, paying for one game with no feedback between games, minimizes such a concern. Paying for one game also helps reduce wealth effects.

\section{Results}

\subsection{Descriptive Statistics}

We start our analysis by discussing sample descriptives. Panel A in Table 2 presents average socio-economic characteristics for our sample. The average participant in our experiment is 24 years old and about $50 \%$ of them are married. The likelihood of secondary school completion is low with only $43 \%$ of women completing ten grades of schooling. Our sample is primarily Hindu (97\%) and more than one-third (37\%) of the women in our sample have some prior experience in tailoring and stitching. Approximately $10 \%$ of the women in our sample belong to the Other Backward Caste (OBC) group. Our subjects reside in households where average household monthly income is approximately Rs 7000 and when compared to average income reported in the 2005 Indian Human Development Survey, these households would lie between

filled bag. In particular, a Research Assistant filled up a bag in front of the subjects to provide an example of a correctly filled bag. He also demonstrated examples of unacceptable performances, that is, when bags are half filled, or are filled but have not been zipped, or are half filled and not zipped. Participants were encouraged to ask any questions they might have on the task and on what constitutes a properly filled bag. 
the $1^{\text {st }}$ and the $5^{\text {th }}$ percentile of the income distribution in urban India and would be identified as poor. $^{18}$

Panel B in Table 2 presents the descriptive statistics for the behavioral traits. Participants on an average allocate Rs 25 (50\% of their endowment) to the risky option in the investment game (indicator of risk tolerance of participants). On an average $36 \%$ of the participants choose to be paid according to the competition rate (indicator of competitive behavior) in the competition game. As in Niederle and Vesterlund (2007), we find participants in our sample to be overconfident (as measured by the confidence ratio). Their ex-ante assessment of number of bags filled is much more than the actual number of bags filled in the real effort task. This is consistent with other experimental research (Croson and Gneezy (2009); Camerer and Lovallo (1999); Merkle and Weber (2011)) and psychological studies (Weinstein (1980); Taylor and Brown (1988); Koellinger et al. (2007)), which find that subjects are often irrationally overconfident about their own abilities.

In Table 2 we also present the averages (and standard deviations) for the sample of applicants and non-applicants and a test of significance of the difference between the two groups. Non-applicants are older, more likely to belong to a backward caste (OBC), less likely to have prior experience in stitching and tailoring, belong to poorer families, and are less happy at home (see column 4 in Panel A) as compared to applicants. Non-applicants also fill more bags in the allotted one-minute and are more impatient (see column 4 in Panel B).

Several other points are worth noting about our sample. First, women who choose the competition-rate compensation method are significantly more likely to place themselves at a higher rank within the group (correlation coefficient is 0.18 with a $p$-value $=0.007$ ). This is not surprising, since in the competition-rate compensation method they will earn a positive amount only if they fill more bags than their competitor, it seems logical to observe that a woman is

${ }^{18}$ Only about $4.9 \%$ of the women in the sample are employed (in causal work or permanent wage employment) and $2.7 \%$ are self-employed. Due to the really low rates of labour force participation among our participants, we find no significant correlation between pre-intervention employment status and measured behavioral traits. 
likely to choose this method of compensation only if she believes herself to be better than others in the group. The choice of the compensation method is however not affected by their expectation of the number of bags they are likely to fill in the allotted one minute (the measure of absolute confidence).

Second, while the average number of bags filled in one minute is significantly higher for women choosing the competition-rate compensation method (2.06 compared to $1.81, p$ value $=0.015$, two-sided t-test), there is no difference in the between-subject variance in the number of bags filled in the allotted one minute depending on the compensation method chosen. Therefore there is no evidence that sorting based on choice of the payment mechanism is efficiency increasing unlike in Eriksson et al. (2009), where the mean of effort is higher and the variance lower with a competitive wage scheme.

Finally, while the two games we chose have some similar characteristics they measure distinct behavioral traits. In terms of similarities it can be argued that there is an element of risk in the competition game as well. Choosing the competition rate as opposed to the piece-rate payment scheme can potentially be a risky alternative since the payoff in this case depends on relative performance and not absolute performance. One could view this as a reflection of participants' attitude towards strategic risk. Competitive women would have invested more in the risky asset if strategic risk were to be positively correlated with exogenous risk, that is, the kind of risk the subject faces in the investment game. To examine this, we test for differences in the amount allocated to the risky asset in the investment game by type of wage scheme chosen in the competition game and find that on an average women chose to invest $50 \%$ of their endowment in the investment game and this does not differ by their decision (piece rate or competitive rate) in the competition game (difference in risk amount $=0.69$ and $p$-value $=0.65$, two-sided t-test). In terms of different features, the choice in the investment game is in response to an endowment, while the choice in the competition game is in response to earnings from a real effort task. Recent research suggests that individuals behave differently depending on 
whether the money is allocated to them or whether they earn it (see, for example, Cherry et al. (2002), Dasgupta (2011), Erkal et al. (2011)). Further, although the relative returns from choosing the riskier alternative were identical in the two games, the expected payoffs across games are different. While there is positive correlation between decisions in the investment game and the competition game, this is not statistically significant $(p$-value $=0.65)$. The lack of significant correlation between the two games therefore suggests that behavior is game specific in the experiment.

\subsection{Regression Results}

The sample is deliberately skewed in favor of the applicants and does not represent the true population. To address this bias, we follow the weighted endogenous sampling maximum likelihood (WESML) estimation technique proposed by Manski and Lerman (1977). This estimation strategy requires that the true population proportions be known for both the applicants and the non-applicants. Fortunately, we have data on both the sample and the population proportion of applicants and non-applicants. Using these proportions, the WESML estimator applies weight $=0.077$ for applicants and weight $=3.32$ for non-applicants .

The weighted probit estimates reported in Table 3 capture the effect of the socioeconomic and behavioral variables on the decision to apply to the program. The marginal effects and robust standard errors are reported in Table 3. Results corresponding to different specifications are presented in columns (1) - (3) in Table 3. In column (1), we include only socio-economic characteristics obtained from the survey. In column (2) we include the proportion of endowment allocated to the risky option in the investment game, choice of the competitive wage scheme in the competition game, and actual performance in the real effort task (number of bags actually filled in the allotted one minute) as additional controls. In column (3) we also control for the confidence ratio. Hence this specification includes the full set of socio-economic characteristics and behavioral traits, and is our preferred specification. Additional specifications to examine the robustness of our results are discussed in Section 3.3. 
The results from the full specification in column (3) of Table 3 show that applicants and non-applicants differ in terms of a number of socio-economic and demographic characteristics. Younger women are more likely to apply to the program. An additional year in age is associated with a 0.3 percentage point reduction in the probability of applying to the program. Women belonging to backward castes are 2 percentage points less likely to apply for the program. ${ }^{19}$ Women with some prior experience in tailoring and stitching are almost 30-percentage points more likely to apply to the program.

Applicant status is affected by household income and dependency ratio (defined as the ratio of the number of children under 5 in a household and the number of adult females in the household). In our sample, a 10,000 Rupee increase in household income, net of the participant's own income, increases the probability of applying to the program by 3-percentage points. Applicants therefore were from relatively richer households (the targeted sample are all disadvantaged, so richer is only defined in a relative sense). Dependency ratio can influence choice in two different ways. First, since women are typically the primary care-givers for children, a woman belonging to a household that has relatively more children compared to the available adult women faces a substantially higher time-cost of participating in the training program. In this case an increase in the dependency ratio might result in a participant substituting away from the training program, and hence reduce the probability of applying to the program. On the other hand, it is often the case that in our subject-pool, it is the woman's responsibility to find the resources required to send children to school or take them to a doctor/hospital when they are sick. Most applicants report that the primary reason for applying to the program is to increase future income. An increase in dependency ratio would put more pressure on the adult woman to seek out additional ways to enhance household income. We would then expect a positive relation between the increase in the dependency ratio and the probability of applying to the program due to the underlying income-earning motive. Which of

\footnotetext{
${ }^{19}$ In the Indian context caste is often a major constraint in applying for training programs and choosing entrepreneurship. See Field et al. (2010).
} 
the two effects is stronger is an empirical question. In our sample, we find that the income earning effect dominates the substitution effect. ${ }^{20}$

Turning to the effects of the behavioral traits, we find that women who have a greater tolerance for risk, i.e., those who choose to invest more in the risky option in the investment game, and prefer a competitive wage scheme are more likely to apply to the vocational training program. A one-percent increase in the proportion of the endowment allocated to the risky option in the investment game is associated with a 6-percentage point increase in the probability of applying to the program (see column (3), Table 3). Women who choose the competitive wage scheme in the competition game are 3-percentage points more likely to apply to the program. A unit increase in the confidence ratio is associated with a 0.3 -percentage point increase in the probability of applying to the program, though this effect is not statistically significant. The effects of risk tolerance and competitiveness persist even when we control for participants' confidence levels. These are large conditional effects, controlling for a rich set of socioeconomic characteristics. The behavioral variables are also always jointly significant in explaining applicant status.

\subsection{Robustness}

We estimate several alternative specifications to ensure that the findings presented in Table 3 are robust. We discuss these robustness tests in this section and Table 4 reports the corresponding results, as before, using the WESML estimation technique. First, in columns (1) and (2) in Table 4 we include alternative measures of confidence: self-assessment of the number of bags they could fill in the real effort task (column (1)) and perceived rank within the group (column (2)). In these two specifications we do not include confidence ratio in the set of

\footnotetext{
${ }^{20}$ We included membership in a Rotating Savings and Credit Association (ROSCA) as an additional explanatory variable in all our regressions. Anderson and Baland (2002) argue that membership in a ROSCA could be viewed as a measure of bargaining power of the woman. Additionally ROSCA participation could also indicate credit or savings constraints or the need to shield earnings from family members. Finally ROSCA participation can be interpreted as a measure of social capital as it is membership in a community organisation. However in none of the regressions, ROSCA membership has a statistically significant effect on the decision to apply to the program.
} 
explanatory variables. A unit increase in the number of bags the woman expects to be able to fill is associated with a 0.2 percentage points increase in the probability of applying for the program. Similarly a unit increase in the perceived rank within the group is associated with a 0.7 percentage point increase in the probability of applying for the program. Though in neither case is the effect statistically significant. The rest of the results remain qualitatively similar.

Second, in column (3) we include an indicator of impatience as an additional control (the rest of the explanatory variables are as in column (3) in Table 3). The rate at which an individual discounts future pay-offs can influence the decision to be an applicant to the program. Returns from a training program (and indeed from all educational programs) require a gestation lag to bear fruit (see for example Mullainathan (2005) for a discussion on how time preference can shape schooling decisions). It is possible that women who have a higher discount rate for future utility might tend to discount the future returns from the program more heavily (i.e., are more impatient) and choose not to apply. To understand patterns of time preference we included a hypothetical question in our household survey where the respondent is asked to choose between a sure prize of Rs 100 today versus Rs 150 one month from today. The variable impatience takes the value of 1 if the respondent chooses Rs 100 today. The results from specification 3 in Table 4 show that consistent with Table 1, the coefficient of the impatience dummy is in the expected direction though it is not statistically significant. The inclusion of this variable does not have any effect on the other explanatory variables (compare column (3) in Tables 3 and 4). ${ }^{21}$

In addition to the specifications reported in Table 4, we conducted a number of other sensitivity checks, which are not reported here given space constraints. First, we investigated whether the effects of the behavioral characteristics are different in economically better-off

\footnotetext{
${ }^{21}$ There are different ways of capturing this impatience. Our measure of impatience is based on hypothetical choices as it was difficult to operationalize the later payments in the field. This hypothetical feature could be the cause of the less significant results for this variable in the regression. Measuring impatience using monetary incentives (see for example Harrison et al. (2002)) would be useful in future research.
} 
households? To examine this we constructed a dummy variable (rich households), which takes the value 1 if the household income is greater than the mean household income for the sample and 0 otherwise. We interacted the three behavioral characteristics with this rich household dummy and included these interaction terms as additional controls. The difference estimate (given by the coefficient estimate of the interaction term) is never statistically significant, indicating that the behavioral characteristics do not have a differential impact on the likelihood of applying to the program across different income levels. Second, the coefficient estimate on risk is robust to the inclusion of variables that capture household wealth, measured by house ownership. We re-estimate our preferred specification in Table 3 including a dummy for house ownership, and find that our results continue to hold. Third, our key results are robust to the inclusion of participant's own income as an additional covariate in the main regression. Finally we explored locational cluster effects. Women in the sample reside in 12 different areas (within South Shahdara). To account for common area level unobservables we include area dummies with robust standard errors. We find that the magnitude and signs of all the coefficient estimates are very similar to those obtained from the estimates reported in column (3) in Table 3. These results are available on request.

\section{Discussion}

This paper uses a novel design that combines household survey data with unique experimental data to shed light on the determinants of self-selection into vocational training programs. Identifying the mechanisms underlying self-selection into training programs can be important for multiple reasons. First, it can enable us to determine which observable characteristics, individual or at the household-level, matter in encouraging the targeted population to apply for training programs. Identification of these determinants can help policy makers decide on the possible role of subsidies and transfers to promote participation (see Heckman (1992)), since low participation can potentially weaken the overall benefits of such programs. Second, very little is known about the individual-level behavioral characteristics such as differences in 
preferences, inherent competitiveness, and other abilities that can potentially influence selfselection into programs. For example, individuals who choose to apply to training programs might be more competitive and confident than the average non-applicant, and ignoring such behavioral characteristics can result in biased program effects.

Using our approach to identify behavioral characteristics along with the demographic and socio-economic characteristics, we find that women who have a greater preference for risk and are more competitive have a higher propensity to apply for the specific training program. The results from our surveys reveal in addition that younger women with prior experience in stitching and tailoring and belonging to households with higher income and dependency ratio, have a significantly higher probability of applying to the stitching and tailoring training program.

Although our analysis focuses on identifying factors that affect self-selection into a specific program for a specific population, we believe that this population is of considerable interest and insights gained from this population can be applied elsewhere. First, the young population in our sample is reflective of the population structure in the majority of developing countries. Second, more than a third of the urban population in developing countries reside in slums and improving the condition of these slum dwellers by providing them marketable skills is of crucial importance to governments and policy makers. Third, in developing countries around the world, women typically have low rates of skill accumulation, and labor force participation. Increasing skills and labor force participation rates of women therefore, can have significant effects on aggregate productivity in these countries (See UNESCO (2012) and Census (2011) for more on these issues). The first step however is to get women to apply to such programs. Lessons from this study are therefore applicable to many other countries facing similar challenges involving demographics, growth, skill accumulation, and development.

The behavioral characteristics we chose to study can influence self-selection decisions of a broader target population into many other skill building programs meant for improving wage and self-employment opportunities. In future, research insights from this project can be 
used to explore additional programs and how differences in measured behavioral traits can potentially explain the heterogeneous policy outcomes often observed in the field: for example, why a program succeeds in certain neighborhoods and not in others, even after controlling for a range of observable characteristics.

The inclusion and better measurement of these behavioral traits can inform policy makers how to devise and advertise new policies aimed at improving participation rates. For example, for an observed level of risk attitudes, a policy can be promoted such that the risk associated with its returns are better articulated, thereby influencing the probability weights used by individuals to calculate their expected payoffs. It is important to note here that there might be other behavioral traits as well, that can differ between applicants and non-applicants. Examining them are beyond the scope of this paper and is left for future research. However, using our approach one can envision policy-makers designing perfectly targeted individualspecific programs where a large set of identified behavioral determinants and their effects are incorporated in the implementation stages of the programs. Although identifying and uncovering behavioural traits using incentivised methods would require resources, they might not be that substantial since these traits could be elicited as part of household surveys (as in Bartling et al. (2009)). Further, identifying the specific sources of behavioral traits can help researchers address the selection issue better by specifically controlling for these characteristics instead of including them in the black box called unobservables. 
Table 1: Distribution of the Sample for the Applicants and Non-Applicants

\begin{tabular}{|c|c|c|c|}
\hline & $\begin{array}{l}\text { Sample Size } \\
\text { Total }\end{array}$ & $\begin{array}{l}\text { Sample size } \\
\text { Applicants }\end{array}$ & $\begin{array}{c}\text { Sample } \\
\text { size } \\
\text { Non- } \\
\text { applicants }\end{array}$ \\
\hline Census/population & 4417 & 244 & 4173 \\
\hline $\begin{array}{l}\text { Invited to participate in the artefactual field } \\
\text { experiment }\end{array}$ & 300 & 200 & 100 \\
\hline Participated in the artefactual field experiment & 222 & 153 & 69 \\
\hline $\begin{array}{l}\text { Participated in the artefactual field experiment and } \\
\text { the household survey (sample used in the final } \\
\text { regression analysis) }\end{array}$ & 204 & 146 & 58 \\
\hline
\end{tabular}


Table 2: Summary Statistics on Socio-economic and Behavioral Characteristics

\begin{tabular}{|c|c|c|c|c|}
\hline Variables & $\begin{array}{c}\text { Full } \\
\text { sample } \\
\text { (1) }\end{array}$ & $\begin{array}{c}\text { Applicants } \\
\text { (2) }\end{array}$ & $\begin{array}{l}\text { Non- } \\
\text { applicants } \\
\text { (3) }\end{array}$ & $\begin{array}{c}\text { Difference } \\
(4)=(2)- \\
(3) \\
\text { [Standard } \\
\text { error] }\end{array}$ \\
\hline \multicolumn{5}{|l|}{ Panel A: Socio-economic characteristics } \\
\hline Age (in years) & $\begin{array}{l}24.57 \\
(6.69)\end{array}$ & $\begin{array}{l}23.74 \\
(5.93)\end{array}$ & $\begin{array}{l}26.66 \\
(7.99)\end{array}$ & $\begin{array}{c}-2.91^{* * *} \\
{[1.02]}\end{array}$ \\
\hline Married & $\begin{array}{c}0.49 \\
(0.50)\end{array}$ & $\begin{array}{c}0.47 \\
(0.50)\end{array}$ & $\begin{array}{c}0.55 \\
(0.50)\end{array}$ & $\begin{array}{c}-0.08 \\
{[0.07]}\end{array}$ \\
\hline Completed secondary school & $\begin{array}{c}0.43 \\
(0.49)\end{array}$ & $\begin{array}{c}0.45 \\
(0.50)\end{array}$ & $\begin{array}{c}0.42 \\
(0.49)\end{array}$ & $\begin{array}{c}0.03 \\
{[0.07]}\end{array}$ \\
\hline OBC & $\begin{array}{c}0.10 \\
(0.30)\end{array}$ & $\begin{array}{c}0.07 \\
(0.26)\end{array}$ & $\begin{array}{c}0.17 \\
(0.38)\end{array}$ & $\begin{array}{l}-0.10 * * \\
{[0.046]}\end{array}$ \\
\hline Hindu & $\begin{array}{c}0.97 \\
(0.16)\end{array}$ & $\begin{array}{c}0.98 \\
(0.14)\end{array}$ & $\begin{array}{c}0.95 \\
(0.22)\end{array}$ & $\begin{array}{c}0.03 \\
{[0.026]}\end{array}$ \\
\hline Experienced in stitching/tailoring & $\begin{array}{c}0.37 \\
(0.48)\end{array}$ & $\begin{array}{c}0.48 \\
(0.50)\end{array}$ & $\begin{array}{c}0.08 \\
(0.28)\end{array}$ & $\begin{array}{c}0.40 * * * \\
{[0.07]}\end{array}$ \\
\hline Happy at home & $\begin{array}{l}0.83 \\
(0.37)\end{array}$ & $\begin{array}{c}0.87 \\
(0.34)\end{array}$ & $\begin{array}{c}0.74 \\
(0.44)\end{array}$ & $\begin{array}{c}0.13^{* *} \\
{[0.06]}\end{array}$ \\
\hline $\begin{array}{l}\text { Family income excluding own income (in } \\
\text { Rupees) }\end{array}$ & $\begin{array}{l}6970.29 \\
(6624.57)\end{array}$ & $\begin{array}{l}7506.442 \\
(6947.04)\end{array}$ & $\begin{array}{c}5620.69 \\
(5561.70)\end{array}$ & $\begin{array}{l}1885.73^{*} \\
{[1022.18]}\end{array}$ \\
\hline Dependency ratio & $\begin{array}{c}0.31 \\
(0.51)\end{array}$ & $\begin{array}{c}0.35 \\
(0.55)\end{array}$ & $\begin{array}{c}0.22 \\
(0.38)\end{array}$ & $\begin{array}{l}-0.13 \\
{[0.08]}\end{array}$ \\
\hline $\begin{array}{l}\text { Member of a ROSCA (Rotating Savings and } \\
\text { Credit Association) }\end{array}$ & $\begin{array}{c}0.10 \\
(0.31)\end{array}$ & $\begin{array}{c}0.13 \\
(0.33)\end{array}$ & $\begin{array}{c}0.05 \\
(0.22)\end{array}$ & $\begin{array}{c}0.08 \\
{[0.05]}\end{array}$ \\
\hline Panel B: Behavioral characteristics & & & & \\
\hline $\begin{array}{l}\text { Proportion allocated to the risky option in the } \\
\text { Investment Game } \\
\text { Self-assessment of number of bags they could } \\
\text { fill in the Competition Game }\end{array}$ & $\begin{array}{c}49.73 \\
(21.39) \\
4.35 \\
(2.36)\end{array}$ & $\begin{array}{c}50.75 \\
(20.44) \\
4.31 \\
(2.00)\end{array}$ & $\begin{array}{c}47.13 \\
(23.60) \\
4.45 \\
(3.10)\end{array}$ & $\begin{array}{c}3.61 \\
{[3.32]} \\
0.14 \\
{[0.36]}\end{array}$ \\
\hline Perceived rank within the group & $\begin{array}{c}4.05 \\
(1.01)\end{array}$ & $\begin{array}{c}4.08 \\
(1.00)\end{array}$ & $\begin{array}{l}3.96 \\
(1.02)\end{array}$ & $\begin{array}{c}0.12 \\
{[0.15]}\end{array}$ \\
\hline $\begin{array}{l}\text { Choice of the competitive wage scheme in the } \\
\text { Competition Game }\end{array}$ & $\begin{array}{c}0.36 \\
(0.48)\end{array}$ & $\begin{array}{l}0.363 \\
(0.48)\end{array}$ & $\begin{array}{l}0.362 \\
(0.48)\end{array}$ & $\begin{array}{c}0.001 \\
{[0.07]}\end{array}$ \\
\hline Number of bags actually filled & $\begin{array}{c}1.89 \\
(0.71)\end{array}$ & $\begin{array}{c}1.82 \\
(0.70)\end{array}$ & $\begin{array}{c}2.06 \\
(0.72)\end{array}$ & $\begin{array}{c}0.25 * * \\
{[0.11]}\end{array}$ \\
\hline Confidence ratio & $\begin{array}{c}2.65 \\
(1.96)\end{array}$ & $\begin{array}{c}2.77 \\
(2.06)\end{array}$ & $\begin{array}{c}2.33 \\
(1.67)\end{array}$ & $\begin{array}{c}0.44 \\
{[0.31]}\end{array}$ \\
\hline Impatience & $\begin{array}{c}0.67 \\
(0.47) \\
\end{array}$ & $\begin{array}{c}0.62 \\
(0.48) \\
\end{array}$ & $\begin{array}{c}0.79 \\
(0.41) \\
\end{array}$ & $\begin{array}{c}-0.17^{* *} \\
{[0.07]}\end{array}$ \\
\hline Sample Size & 204 & 146 & 58 & 204 \\
\hline $\begin{array}{l}\text { Notes: Standard deviations are reported in parentheses. St } \\
\text { dummy for women with at least } 10 \text { grades of schooling. } \mathrm{O} \\
\text { government of India to classify economically and socially } \\
\text { belong to scheduled caste, scheduled tribe, or general caste } \\
\text { under } 5 \text { divided by the number of adult females in the hou } \\
\text { is very satisfied or moderately satisfied at home, } 0 \text { otherv } \\
\text { subject expects to fill to the number of bags she actually fi } \\
\text { Table correspond to those included as explanatory variab } \\
\mathrm{p}<0.05,{ }^{*} \mathrm{p}<0.1 \text {. }\end{array}$ & $\begin{array}{l}\text { is a dummy fo } \\
\text { dvantaged grou } \\
\text { ependency ratio } \\
\text { ld. Happy at h } \\
\text { Confidence rc } \\
\text { erceived rank } \\
n \text { the regressio }\end{array}$ & $\begin{array}{l}\text { Dther Backward } \\
\text { ). The reference } \\
\text { defined as the } \\
\text { ne is a dummy t } \\
\text { o is defined as } \\
1 \text { if lowest, = } 5 \\
\text { results reported }\end{array}$ & $\begin{array}{l}\text { stes (a classif } \\
\text { te categories } \\
\text { aber of childre } \\
\text { takes a value } \\
\text { ratio of the } n \\
\text { ighest. Variab } \\
\text { Tables } 3 \text { and }\end{array}$ & $\begin{array}{l}\text { dary school is a } \\
\text { tion used by the } \\
\text { households that } \\
\mathrm{n} \text { the household } \\
\mathrm{f} \text { the respondent } \\
\text { ber of bags the } \\
\text { included in this } \\
* * * \mathrm{p}<0.01 \text {, }\end{array}$ \\
\hline
\end{tabular}


Table 3: Determinants of Applicant Status: Marginal Effects from a Weighted Probit Regression

\begin{tabular}{|c|c|c|c|}
\hline & (1) & (2) & (3) \\
\hline \multicolumn{4}{|l|}{ Socio-economic characteristics } \\
\hline Age (in years) & $\begin{array}{c}-0.003^{* *} \\
(0.001)\end{array}$ & $\begin{array}{l}-0.003^{* *} \\
(0.001)\end{array}$ & $\begin{array}{c}-0.003^{* * *} \\
(0.001)\end{array}$ \\
\hline Completed secondary school & $\begin{array}{l}-0.015 \\
(0.012)\end{array}$ & $\begin{array}{l}-0.013 \\
(0.010)\end{array}$ & $\begin{array}{c}-0.014 \\
(0.010)\end{array}$ \\
\hline OBC & $\begin{array}{c}-0.023^{* *} \\
(0.009)\end{array}$ & $\begin{array}{c}-0.021 * * * \\
(0.008)\end{array}$ & $\begin{array}{c}-0.021 * * * \\
(0.007)\end{array}$ \\
\hline Hindu & $\begin{array}{l}0.018^{*} \\
(0.011)\end{array}$ & $\begin{array}{l}-0.001 \\
(0.017)\end{array}$ & $\begin{array}{c}-0.005 \\
(0.019)\end{array}$ \\
\hline Experienced in stitching/tailoring & $\begin{array}{c}0.190^{* *} \\
(0.074)\end{array}$ & $\begin{array}{c}0.284^{* * *} * \\
(0.079)\end{array}$ & $\begin{array}{c}0.288 * * * \\
(0.078)\end{array}$ \\
\hline $\begin{array}{l}\text { Family income excluding own income (in } \\
\text { 0000 Rupees) }\end{array}$ & $\begin{array}{l}0.029 * * * \\
(0.010)\end{array}$ & $\begin{array}{c}0.030 * * * \\
(0.009)\end{array}$ & $\begin{array}{c}0.029 * * * \\
(0.009)\end{array}$ \\
\hline Married & $\begin{array}{l}-0.009 \\
(0.019)\end{array}$ & $\begin{array}{l}-0.004 \\
(0.014)\end{array}$ & $\begin{array}{l}-0.002 \\
(0.013)\end{array}$ \\
\hline Dependency ratio & $\begin{array}{c}0.034^{* *} \\
(0.015)\end{array}$ & $\begin{array}{c}0.027 * * \\
(0.013)\end{array}$ & $\begin{array}{l}0.025^{*} \\
(0.013)\end{array}$ \\
\hline Happy at home & $\begin{array}{c}0.024^{* *} \\
(0.011)\end{array}$ & $\begin{array}{c}0.014 \\
(0.009)\end{array}$ & $\begin{array}{c}0.014 \\
(0.009)\end{array}$ \\
\hline Member of a ROSCA & $\begin{array}{c}0.016 \\
(0.042)\end{array}$ & $\begin{array}{c}0.033 \\
(0.047)\end{array}$ & $\begin{array}{c}0.036 \\
(0.050)\end{array}$ \\
\hline Number of bags actually filled & & $\begin{array}{c}-0.022 * * * \\
(0.008)\end{array}$ & $\begin{array}{c}-0.019 * * \\
(0.008)\end{array}$ \\
\hline \multicolumn{4}{|l|}{ Behavioral Characteristics } \\
\hline $\begin{array}{l}\text { Proportion allocated to the risky option in the } \\
\text { Investment Game } \times 10^{-2} \\
\text { Choice of the competitive wage scheme in the } \\
\text { Competition Game } \\
\text { Confidence ratio }\end{array}$ & & $\begin{array}{c}0.055 * * \\
(0.024) \\
0.031 * * \\
(0.016)\end{array}$ & $\begin{array}{c}0.059 * * \\
(0.025) \\
0.030 * * \\
(0.015) \\
0.003 \\
(0.002)\end{array}$ \\
\hline Joint Significance (Behavioral variables) & & $17.60 * * *$ & $19.26 * * *$ \\
\hline $\begin{array}{l}\text { Sample Size } \\
\text { Predicted Probability } \\
\text { Pseudo R-squared } \\
\text { Log Likelihood }\end{array}$ & $\begin{array}{c}204 \\
0.024 \\
0.22 \\
-33.74\end{array}$ & $\begin{array}{c}204 \\
0.018 \\
0.29 \\
-30.93\end{array}$ & $\begin{array}{c}204 \\
0.018 \\
0.29 \\
-30.72\end{array}$ \\
\hline
\end{tabular}


Table 4: Determinants of Applicant Status: Robustness (Marginal Effects from a Weighted Probit Regression)

\begin{tabular}{|c|c|c|c|}
\hline & (1) & (2) & (3) \\
\hline \multicolumn{4}{|l|}{ Socio-economic characteristics } \\
\hline Age (in years) & $\begin{array}{c}-0.003 * * * \\
(0.001)\end{array}$ & $\begin{array}{l}-0.003 * * * \\
(0.001)\end{array}$ & $\begin{array}{c}-0.003 * * * \\
(0.001)\end{array}$ \\
\hline Completed secondary school & $\begin{array}{l}-0.014 \\
(0.010)\end{array}$ & $\begin{array}{l}-0.015 \\
(0.010)\end{array}$ & $\begin{array}{l}-0.015 \\
(0.010)\end{array}$ \\
\hline OBC & $\begin{array}{l}-0.021^{* * *} \\
(0.007)\end{array}$ & $\begin{array}{l}-0.020^{* * *} \\
(0.007)\end{array}$ & $\begin{array}{c}-0.021 * * * \\
(0.007)\end{array}$ \\
\hline Hindu & $\begin{array}{l}-0.004 \\
(0.019)\end{array}$ & $\begin{array}{c}0.004 \\
(0.014)\end{array}$ & $\begin{array}{l}-0.012 \\
(0.023)\end{array}$ \\
\hline Experienced in stitching/tailoring & $\begin{array}{c}0.295 * * * \\
(0.078)\end{array}$ & $\begin{array}{c}0.287 * * * \\
(0.081)\end{array}$ & $\begin{array}{c}0.268 * * * \\
(0.078)\end{array}$ \\
\hline $\begin{array}{l}\text { Family income excluding own income (in } \\
0000 \text { Rupees) }\end{array}$ & $\begin{array}{c}0.030 * * * \\
(0.009)\end{array}$ & $\begin{array}{l}0.032 * * * \\
(0.009)\end{array}$ & $\begin{array}{c}0.029 * * * \\
(0.008)\end{array}$ \\
\hline Married & $\begin{array}{l}-0.002 \\
(0.014)\end{array}$ & $\begin{array}{l}-0.005 \\
(0.014)\end{array}$ & $\begin{array}{c}0.004 \\
(0.013)\end{array}$ \\
\hline Dependency ratio & $\begin{array}{l}0.026 * * \\
(0.013)\end{array}$ & $\begin{array}{l}0.028 * * \\
(0.013)\end{array}$ & $\begin{array}{l}0.021^{*} \\
(0.012)\end{array}$ \\
\hline Happy at home & $\begin{array}{c}0.013 \\
(0.010)\end{array}$ & $\begin{array}{c}0.011 \\
(0.010)\end{array}$ & $\begin{array}{c}0.013 \\
(0.009)\end{array}$ \\
\hline Member of a ROSCA & $\begin{array}{c}0.033 \\
(0.048)\end{array}$ & $\begin{array}{c}0.043 \\
(0.054)\end{array}$ & $\begin{array}{c}0.048 \\
(0.055)\end{array}$ \\
\hline Number of bags actually filled & $\begin{array}{c}-0.023 * * * \\
(0.008)\end{array}$ & $\begin{array}{c}-0.023 * * * \\
(0.008)\end{array}$ & $\begin{array}{c}-0.019 * * \\
(0.008)\end{array}$ \\
\hline \multicolumn{4}{|l|}{ Behavioral Characteristics } \\
\hline $\begin{array}{l}\text { Proportion allocated to the risky option in the } \\
\text { Investment Game } \times 10^{-2}\end{array}$ & $\begin{array}{l}0.060 * * \\
(0.025)\end{array}$ & $\begin{array}{c}0.050 * * \\
(0.023)\end{array}$ & $\begin{array}{l}0.060 * * \\
(0.024)\end{array}$ \\
\hline $\begin{array}{l}\text { Choice of the competitive wage scheme in the } \\
\text { Competition Game }\end{array}$ & $\begin{array}{l}0.030 * * \\
(0.015)\end{array}$ & $\begin{array}{l}0.028 * \\
(0.015)\end{array}$ & $\begin{array}{l}0.030 * * \\
(0.015)\end{array}$ \\
\hline $\begin{array}{l}\text { Self-assessment of number of bags they could } \\
\text { fill in the Competition Game }\end{array}$ & $\begin{array}{l}0.001 \\
(0.001)\end{array}$ & & \\
\hline $\begin{array}{l}\text { Perceived rank within the group ( } 1 \text { = Lowest, } \\
5 \text { = Highest) }\end{array}$ & & $\begin{array}{c}0.007 \\
(0.005)\end{array}$ & \\
\hline Impatience & & & $\begin{array}{l}-0.021 \\
(0.015)\end{array}$ \\
\hline Confidence ratio & & & $\begin{array}{c}0.003 \\
(0.002)\end{array}$ \\
\hline Joint Significance (Behavioral variables) & $18.38 * * *$ & $19.56 * * *$ & $21.47 * * *$ \\
\hline Sample Size & 204 & 204 & 204 \\
\hline Predicted Probability & 0.018 & 0.018 & 0.017 \\
\hline Pseudo R-squared & 0.29 & 0.29 & 0.30 \\
\hline Log Likelihood & -30.81 & -30.53 & -30.30 \\
\hline
\end{tabular}


Figure 1: Advertisement Pamphlet for the Training Program

\section{Free Stitching and Tailoring Course for Women \\ Conducted by}

Social Awakening through youth Action

(SATYA)

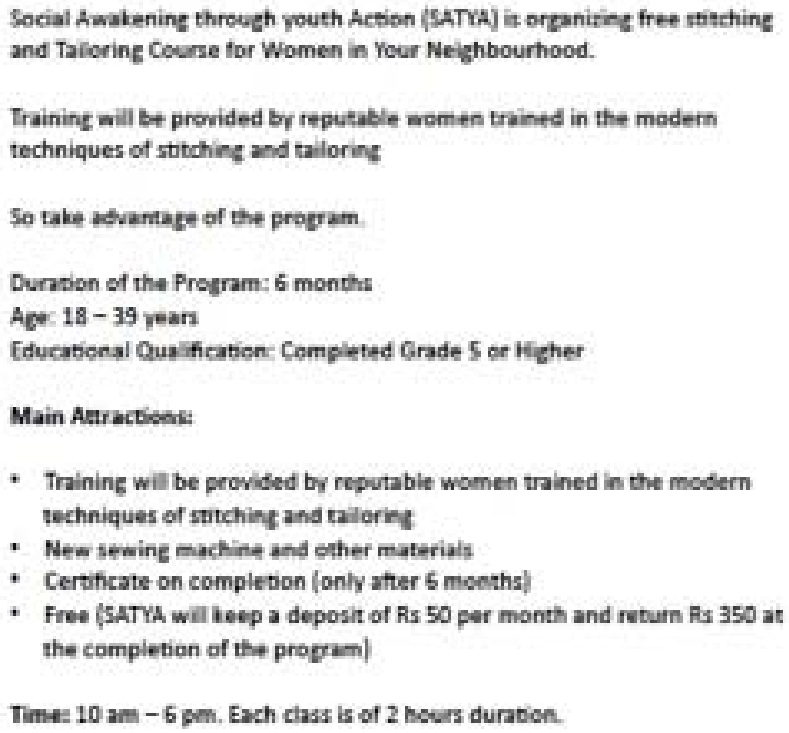

- Training will be provided by reputabie women trained in the modern techniques of statching and talloring

- New sewine machine and other materials

- Certificate on completion (only after 6 months?

- Free (SATYA will heep a deposit of Rs 50 per month and return Rs 350 at the completion of the program)

Time: 10 am $-6 \mathrm{pm}$. Each class is of 2 beurs duration. 
Andersen, S., S. Ertac, U. Gneezy, J. List and S. Maximiano (2010). Gender, Competitiveness and Socialization at a Young Age: Evidence from a Matrilineal and a Patriarchal Society, . Mimeo University of Chicago.

Anderson, S. and J.-M. Baland (2002): "The Economics of Roscas and Intrahousehold Resource Allocation", Quarterly Journal of Economics, 117(3), 963 - 995.

Attanasio, P. O., A. D. Kugler and C. Meghir (2011): "Subsidizing Vocational Training for Disadvantaged Youth in Colombia: Evidence from a Randomized Trial", American Economic Journal: Applied Economics, 3(3), 188 - 220.

Bandiera, O., N. Buehren, R. Burgess, M. Goldstein, S. Gulesci, I. Rasul and M. Sulaiman (2012). Empowering adolescent girls: Evidence from a randomized control trial in Uganda. Mimeo, LSE.

Barnhardt, S., D. Karlan and S. Khemani (2009): "Participation in a School Incentive Programme in India", Journal of Development Studies, 45(3), 369 - 390.

Bartling, B., E. Fehr, M. A. Marechal and D. Schunk (2009): "Egalitarianism and Competitiveness", American Economic Review: Papers and Proceedings, 99(2), 93 - 98.

Bauernschuster, S., O. Falck and S. Heblich (2010): "Social capital access and entrepreneurship", Journal of Economic Behavior \& Organization, 76(3), 821 - 833.

Belzil, C. and M. Leonardi (2009). Risk Aversion and Schooling Decisions. Ecole Polytechnique, Working Paper \# 2009-028. .

Bénabou, R. and J. Tirole (2002): "Self Confidence and Personal Motivation", Quarterly Journal of Economics, 117(3), 871 - 915.

Bernardo, A. E. and I. Welch (2001): "On the Evolution of Overconfidence and Entrepreneurs", Journal of Economics and Management Strategy, 10(3), 301 - 330.

Biais, B., D. Hilton, K. Mazurier and S. Pouget (2005): "Judgemental Overconfidence, Self-Monitoring, and Trading Performance in an Experimental Financial Market", Review of Economic Studies, 72(2), 287 $-312$.

Blattman, C., N. Fiala and S. Martinez (2014): "Generating Skilled Self-Employment in Developing Countries: Experimental Evidence from Uganga", Quarterly Journal of Economics, 129(2), 287 - 312.

Bonin, H., T. Dohmen, A. Falk, D. Huffman and U. Sunde (2007): "Cross-sectional earnings risk and occupational sorting: The role of risk attitudes", Labour Economics, 14(6), 926 - 937.

Buser, T., M. Niederle and H. Oosterbeek (2012): "Gender, Competitiveness and Career Choices", NBER Working Paper, \# 18576.

Camerer, C. F. and D. Lovallo (1999): "Overconfidence and Excess Entry: An Experimental Approach", American Economic Review, 89, 306 - 318.

Cameron, L. A., N. Erkal, L. Gangadharan and X. Meng (2013): "Little Emperors: Behavioural Impacts of China’s One-Child Policy", Science, 339(6122), 953 - 957.

Cardenas, J. C. and J. Carpenter (2008): "Behavioural Development Economics: Lessons from the Field Labs in the Developing World", Journal of Development Studies, 44(3), 311 - 338.

Castillo, M., R. Petrie and M. Torero (2010): "On the Preferences of Principals and Agents", Economic Inquiry, 48(2), 266 - 273. 
Census (2011): "http://censusindia.gov.in/2011-prov-results/data_files/mp/07Literacy.pdf, Registrar General of India.

Charness, G., U. Gneezy and M. A. Kuhn (2013): "Experimental Methods: Extra-Laboratory Experiments-Extending the Reach of Experimental Economics", Journal of Economic Behavior \& Organization, 91, 93 - 100.

Chen, S. (2003). Risk Attitude and College Attendance. Mimeo, SUNY Albany.

Cherry, T. L., P. Frykblom and J. F. Shogren (2002): "Hardnose the Dictator", American Economic Review, 92(4), 1218-1221.

Cooper, A. C., C. A. Woo and W. Dunkelberg (1988): "Entrepreneurs Perceived Chances for Success", Journal of Business Venturing, 3, 97 - 108.

Cramer, J. S., J. Hartog, N. Jonker and C. M. Van Praag (2002): "Low risk aversion encourages the choice for entrepreneurship: an empirical test of a truism", Journal of Economic Behavior \& Organization, 48(1), 29 - 36.

Croson, R. and U. Gneezy (2009): "Gender Differences in Preferences", Journal of Economic Literature, 47(2), 448 - 474.

Dasgupta, U. (2011): "Do Procedures matter in fairness allocations? Experimental evidence in mixed gender pairings", Economics Bulletin, 31, 820 - 829.

Eriksson, T., S. Teyssier and M. C. Villeval (2009): "Self-Selection and the Efficiency of Tournaments", Economic Inquiry, 47(3), 530 - 548.

Erkal, N., L. Gangadharan and N. Nikoforakis (2011): "Relative Earnings and Giving in a Real-Effort Experiment", American Economic Review, 101(7), 3330 - 3348.

Fang, H. and G. Moscarini (2005): "Morale hazard", Journal of Monetary Economics, 52(4), 749 - 777.

Field, E., S. Jayachandran and R. Pande (2010): "Do Traditional Institutions Constrain Female Entrepreneurship? A Field Experiment on

Business Training in India", American Economic Review: Papers and Proceedings, 100(2), 125 - 129.

Filippin, A. and M. Paccagnella (2009). Family Background, Self-Confidence and Economic Outcomes. Mimeo.

Flory, J. A., A. Leibbrandt and J. A. List (2010): "Do competitive work places deter female wokers? A large scale natural field experiemnt on gender differences in job entry decisions", NBER working paper \# 16546.

Gneezy, U., K. L. Leonard and J. List (2009): "Gender Differences in Competition: Evidence from a Matrilineal and Patriarchal Society", Econometrica, 77(5), 1637 - 1664.

Harrison, G. W., W. M. Lau and M. B. Williams (2002): "Estimating Individual Discount Rates in Denmark: A Field Experiment", American Economic Review, 92(5), 1606 - 1617.

Harrison, G. W. and J. List (2004): "Field Experiments", Journal of Economic Literature, 1009 - 1055.

Heckman, J. J. (1992). Randomization and Social Policy Evaluation. NBER Technical Working Paper Series \# 107.

Heckman, J. J. and J. A. Smith (2004): "The Determinants of Participation in a Social Program: Evidence from a Prototypical Job Training Program", Journal of Labor Economics, 22(2), 243 - 298. 
Koellinger, P., M. Minniti and C. Schade (2007): "'I think I can, I think I can’: Overconfidence and Entrepreneurial Behavior", Journal of Economic Psychology, 28, 502 - 527.

Koszegi, B. (2006): "EgoUtility, Overconfidence, and Task Choice", Journal of the European Economic Association, 4(4), 673 - 707.

Liu, E. M. (2008). Time to Change What to Sow: Risk Preferences and Technology Adoption Decisions of Cotton Farmers in China. Working Paper \#1064, Princeton University, Department of Economics, Industrial Relations Section.

Maitra, P. and S. Mani (2013). Learning and Earning: Evidence from a Randomized Evaluation in India. Mimeo Fordham University.

Manski, C. and S. Lerman (1977): "The Estimation of Choice Probabilities from Choice Based Samples", Econometrica, 45, 1977 - 1988.

McKenzie, D., J. Gibson and S. Stillman (2010): "How Important is Selection? Experimental vs. NonExperimental Measures of the Income Gains from Migration", Journal of the European Economic Association, 8(4), 913 - 945.

Merkle, C. and M. Weber (2011): "True overconfidence: The inability of rational information processing to account for apparent overconfidence", Organizational Behavior and Human Decision Processes, 116(2), $262-271$.

Mullainathan, S. (2005). Development Economics through the Lens of Psychology Annual World Bank Conference on Development Economics.

Niederle, M. and L. Vesterlund (2007): "Do Women Shy away from Competition? Do Men Compete too Much?", Quarterly Journal of Economics, 122(3), 1067 - 1101.

Pfeifer, C. (2011): "Risk Aversion and Sorting into Public Sector Employment", German Economic Review, 12, 85 - 99.

Pratham (2006): "Annual Status of Education Report.", Pratham Delhi Education Initiative, New Delhi.

Taylor, S. E. and J. D. Brown (1988): "Illusion and Well-Being: A Social Psychological Perspective on Mental Health", Psychological Bulletin, 103(2), 193 - 210.

UNESCO (2012): "Youth and Skills: Putting Education to Work", UNESCO Education for all Global Monitoring Report.

Weinstein, N. D. (1980): "Unrealistic Optimism About Future Life Events", Journal of Personality and Social Psychology, 39(5), 806 - 820. 


\section{Appendix 1:}

Table A1: Non-response in the artefactual field experiment, survey representativeness, and non-response in the household survey

Panel A: Determinants of non-response in the artefactual field experiment

\begin{tabular}{|c|c|c|c|c|c|c|}
\hline & \multicolumn{3}{|c|}{ Applicant } & \multicolumn{3}{|c|}{ Non-Applicant } \\
\hline & $\begin{array}{l}\text { Invited } \\
\text { and } \\
\text { showed- } \\
\text { up in the } \\
\text { experime } \\
\text { nts }\end{array}$ & $\begin{array}{l}\text { Invited and } \\
\text { did not } \\
\text { show up in } \\
\text { the } \\
\text { experiments }\end{array}$ & Difference & $\begin{array}{l}\text { Invited and } \\
\text { showed-up } \\
\text { in the } \\
\text { experiments }\end{array}$ & $\begin{array}{l}\text { Invited and } \\
\text { did not } \\
\text { show up in } \\
\text { the } \\
\text { experiments }\end{array}$ & Difference \\
\hline & (1) & (2) & $(3=1-2)$ & (4) & (5) & $(6=4-5)$ \\
\hline Age & $\begin{array}{l}23.83 \\
(6.03)\end{array}$ & $\begin{array}{l}24.89 \\
(6.81)\end{array}$ & $\begin{array}{c}-1.06 \\
{[1.03]}\end{array}$ & $\begin{array}{l}26.14 \\
(6.34)\end{array}$ & $\begin{array}{l}26.58 \\
(6.64)\end{array}$ & $\begin{array}{c}-0.43 \\
{[1.39]}\end{array}$ \\
\hline $\begin{array}{l}\text { Completed } \\
\text { grades of } \\
\text { schooling }\end{array}$ & $\begin{array}{c}9.01 \\
(2.49)\end{array}$ & $\begin{array}{c}9.17 \\
(2.58)\end{array}$ & $\begin{array}{c}-0.16 \\
{[0.42]}\end{array}$ & $\begin{array}{c}9.39 \\
(2.63)\end{array}$ & $\begin{array}{c}9.09 \\
(2.72)\end{array}$ & $\begin{array}{c}0.30 \\
{[0.57]}\end{array}$ \\
\hline Sample Size & 153 & 47 & & 69 & 31 & \\
\hline
\end{tabular}

Panel B: Sample representativeness in the artefactual field experiments

\begin{tabular}{|c|c|c|c|c|c|c|}
\hline & \multicolumn{3}{|c|}{ Applicant } & \multicolumn{3}{|c|}{ Non-Applicant } \\
\hline & $\begin{array}{c}\text { Invited } \\
\text { and } \\
\text { showed- } \\
\text { up in the } \\
\text { experime } \\
\text { nts }\end{array}$ & $\begin{array}{l}\text { All other } \\
\text { applicants } \\
\text { from the } \\
\text { census }\end{array}$ & Difference & $\begin{array}{l}\text { Invited } \\
\text { and } \\
\text { showed-up } \\
\text { in the } \\
\text { experiment }\end{array}$ & $\begin{array}{l}\text { All other } \\
\text { non- } \\
\text { applicants } \\
\text { from the } \\
\text { census }\end{array}$ & Difference \\
\hline & (1) & (2) & $(3=1-2)$ & (4) & (5) & $(6=4-5)$ \\
\hline Age & $\begin{array}{l}23.83 \\
(6.03)\end{array}$ & $\begin{array}{l}24.76 \\
(7.17)\end{array}$ & $\begin{array}{c}-0.93 \\
{[0.86]}\end{array}$ & $\begin{array}{l}26.14 \\
(6.35)\end{array}$ & $\begin{array}{l}26.03 \\
(6.17)\end{array}$ & $\begin{array}{c}0.11 \\
{[0.75]}\end{array}$ \\
\hline $\begin{array}{l}\text { Completed } \\
\text { grades of } \\
\text { schooling }\end{array}$ & $\begin{array}{c}9.01 \\
(2.50)\end{array}$ & $\begin{array}{c}9.53 \\
(2.56)\end{array}$ & $\begin{array}{c}-0.52 \\
{[0.33]}\end{array}$ & $\begin{array}{c}9.39 \\
(2.63)\end{array}$ & $\begin{array}{c}9.18 \\
(2.52)\end{array}$ & $\begin{array}{c}0.21 \\
{[0.30]}\end{array}$ \\
\hline Sample Size & 153 & 91 & & 69 & 4104 & \\
\hline
\end{tabular}

Panel C: Determinants of non-response in the household survey 


\begin{tabular}{|c|c|c|c|c|c|c|}
\hline & $\begin{array}{l}\text { Participa } \\
\text { ted in } \\
\text { the } \\
\text { experime } \\
\text { nt and } \\
\text { househol } \\
\text { d survey }\end{array}$ & $\begin{array}{l}\text { Participate } \\
\text { d in the } \\
\text { experiment } \\
\text { but not the } \\
\text { household } \\
\text { survey }\end{array}$ & Difference & $\begin{array}{l}\text { Participated } \\
\text { in the } \\
\text { experiment } \\
\text { and } \\
\text { household } \\
\text { survey }\end{array}$ & $\begin{array}{l}\text { Participated } \\
\text { in the } \\
\text { experiment } \\
\text { but not the } \\
\text { household } \\
\text { survey }\end{array}$ & Difference \\
\hline & (1) & (2) & $(3=1-2)$ & (4) & (5) & $(6=4-5)$ \\
\hline Age & $\begin{array}{l}23.85 \\
(6.06)\end{array}$ & $\begin{array}{l}23.57 \\
(5.80)\end{array}$ & $\begin{array}{c}0.27 \\
{[2.34]}\end{array}$ & $\begin{array}{l}25.60 \\
(6.36)\end{array}$ & $\begin{array}{c}29 \\
(5.72)\end{array}$ & $\begin{array}{l}-3.39 \\
{[2.06]}\end{array}$ \\
\hline $\begin{array}{l}\text { Completed } \\
\text { grades of } \\
\text { schooling }\end{array}$ & $\begin{array}{c}9.01 \\
(2.48)\end{array}$ & $\begin{array}{c}9.00 \\
(2.88)\end{array}$ & $\begin{array}{c}0.01 \\
{[0.96]}\end{array}$ & $\begin{array}{c}9.41 \\
(2.61)\end{array}$ & $\begin{array}{c}9.27 \\
(2.90)\end{array}$ & $\begin{array}{c}0.14 \\
{[0.87]}\end{array}$ \\
\hline Sample Size & 146 & 7 & & 58 & 11 & \\
\hline
\end{tabular}

Panel D: Determinants of non-response in the artefactual field experiment (pooled)

\begin{tabular}{lccc}
\hline & $\begin{array}{c}\text { Invited and } \\
\text { participated in the } \\
\text { artefactual field } \\
\text { experiment }\end{array}$ & $\begin{array}{c}\text { Invited but did not } \\
\text { participate in the } \\
\text { artefactual field } \\
\text { experiment }\end{array}$ & Difference \\
\hline Age & $\mathbf{( 1 )}$ & $\mathbf{( 2 )}$ & $\mathbf{( 3 = 1 - 2 )}$ \\
Completed & 24.55 & 25.56 & -1.01 \\
grades of & $(6.20)$ & $(6.75)$ & {$[0.83]$} \\
schooling & 9.13 & 9.14 & -0.01 \\
\hline & $(2.54)$ & $(2.62)$ & {$[0.33]$} \\
Sample size & 222 & 78 & \\
\hline
\end{tabular}

Panel E: Determinants of non-response in the artefactual field experiment and household survey (pooled)

\begin{tabular}{|c|c|c|c|}
\hline & $\begin{array}{l}\text { Invited and } \\
\text { participated in the } \\
\text { artefactual field } \\
\text { experiment and the } \\
\text { household survey }\end{array}$ & $\begin{array}{l}\text { Invited but did not } \\
\text { participate in the } \\
\text { artefactual field } \\
\text { experiment or the } \\
\text { household survey }\end{array}$ & Difference \\
\hline & (1) & (2) & $(3=1-2)$ \\
\hline Age & $\begin{array}{l}24.34 \\
(6.18)\end{array}$ & $\begin{array}{l}25.81 \\
(6.64)\end{array}$ & $\begin{array}{c}-1.46 * \\
{[0.78]}\end{array}$ \\
\hline $\begin{array}{l}\text { Completed } \\
\text { grades of } \\
\text { schooling } \\
\end{array}$ & $\begin{array}{c}9.12 \\
(2.52)\end{array}$ & $\begin{array}{c}9.14 \\
(2.64)\end{array}$ & $\begin{array}{c}-0.02 \\
{[0.31]}\end{array}$ \\
\hline Sample size & 204 & 96 & \\
\hline
\end{tabular}


Table A2: Summary Statistics of Behavioral Outcomes by Missing and Non-missing Survey Data

\begin{tabular}{|c|c|c|c|}
\hline & $\begin{array}{c}\text { Sample } \\
\text { without } \\
\text { missing } \\
\text { survey } \\
\text { data } \\
\text { (1) }\end{array}$ & $\begin{array}{c}\text { Sample } \\
\text { with } \\
\text { missing } \\
\text { survey } \\
\text { data } \\
\text { (2) }\end{array}$ & Difference \\
\hline Amount allocated to the risky option in the Investment & 24.86 & 24.44 & 0.42 \\
\hline Game & $(10.69)$ & $(10.56)$ & {$[2.63]$} \\
\hline Proportion allocated to the risky option in the & 49.73 & 48.89 & 0.84 \\
\hline Investment Game & $(21.39)$ & $(21.11)$ & {$[5.25]$} \\
\hline Self-assessment of number of bags they could fill in the & 4.35 & 4.33 & 0.02 \\
\hline Competition Game & $(2.36)$ & $(2.58)$ & {$[0.59]$} \\
\hline Perceived rank within group (1 = Lowest, 5 = Highest) & $\begin{array}{c}4.05 \\
(1.01)\end{array}$ & $\begin{array}{c}3.89 \\
(1.18)\end{array}$ & $\begin{array}{c}0.16 \\
{[0.25]}\end{array}$ \\
\hline Choice of the competitive wage scheme in the & 0.36 & 0.28 & 0.08 \\
\hline Competition Game & $(0.48)$ & $(0.46)$ & {$[0.12]$} \\
\hline \multirow[t]{2}{*}{ Number of bags actually filled } & 1.89 & 2.00 & -0.11 \\
\hline & $(0.71)$ & (1.03) & {$[0.18]$} \\
\hline \multirow{2}{*}{ Confidence ratio } & 2.64 & 2.44 & 0.20 \\
\hline & (1.96) & (1.39) & {$[0.47]$} \\
\hline Sample Size & 204 & 18 & \\
\hline
\end{tabular}


Table A3: Non-Response in Surveys: Marginal Effects from Probit Regressions

\begin{tabular}{lc}
\hline Covariates & Non-response \\
\hline Proportion allocated to the risky option in the Investment Game $\left(\times 10^{-2}\right)$ & -0.033 \\
Choice of the competitive wage scheme in the Competition Game & $(0.099)$ \\
& -0.024 \\
Number of bags actually filled & $(0.049)$ \\
& -0.011 \\
Confidence ratio & $(0.036)$ \\
& -0.008 \\
Applicant status (=1 if applicant) & $(0.012)$ \\
& -0.425 \\
Proportion allocated to the risky option in the Investment Game $\times$ & $(0.349)$ \\
Applicant status & 0.081 \\
Choice of the competitive wage scheme in the Competition Game $\times$ & $(0.147)$ \\
Applicant status & -0.006 \\
Number of bags actually filled $\times$ Applicant status & $(0.066)$ \\
Confidence ratio $\times$ Applicant status & 0.046 \\
& $(0.058)$ \\
\hline Sample size & 0.015 \\
\hline
\end{tabular}

Notes: Robust standard errors in parentheses.

$* * * p<0.01, * * p<0.05, * p<0.1$. None of the coefficients are statistically significant.

Non-response is defined as a dummy variable which takes a value 1 if missing information on household questionnaire data and zero otherwise. 


\section{Appendix 2: English Version of the Subject Instructions}

\section{General Instructions}

Player ID \#:

Thank you for your participation. You will be paid Rs. 150 for your participation. There are 2 tasks that we will ask you to participate in. Performing each task can win you more money in cash, in addition to the guaranteed Rs. 150.

Although, each of you will complete both the tasks, only one of them will be chosen for payments. I will toss a coin at the end of the two tasks in front of everyone to determine the task you will be paid for. Note that everyone will be paid according to their performances in the task determined by the coin toss.

We are about to begin the first task. Please listen carefully. It is important that you understand the rules of the task properly. If you do not understand, you will not be able to participate effectively. We will explain the task and go through some examples together. There is to be no talking or discussion of the task amongst you. There will be opportunities to ask questions to be sure that you understand how to perform each task. At any time whilst you are waiting during this experiment, please remain seated, and do not do anything unless instructed by the experimenter. Also do not look at others responses at any time during this experiment.

Finally, each page has an ID\# on it. Do not show this ID\# to any other participant or allow it to be visible to anyone during or after this experiment.

If you are ready, then we will proceed. 


\section{Instructions for the Investment Game \\ Player ID \#:}

We are about to begin the first task. Please listen carefully to the instructions.

In this task, you are provided Rs.50. You have the opportunity to invest a portion of this amount (between Rs.0 and Rs.50). No money will be given at this point. All actual payments will be made at the end of the experiment if this task is chosen as the one that you will be paid for.

\section{The investment:}

There is an equal chance that the investment will fail or succeed. If the investment fails, you lose the amount you invested. If the investment succeeds, you receive 4 times the amount invested.

How do we determine the outcome of the investment:

After you have chosen how much you wish to invest, you will toss a coin to determine whether your investment has failed or succeeded, if this task is chosen for payment. If the coin comes up heads, you win four times the amount you chose to invest. If it comes up tails, you lose the amount invested. You will toss the coin at the end of the experiment, when you come to collect your payment.

Here are some examples:

1. You choose to invest nothing. You will get Rs.50 for sure if this task is chosen for payment.

2. You choose to invest all of the Rs.50. Then if the coin comes up heads, you get Rs.200. If the coin comes up tails, you get Rs.0.

3. You choose to invest Rs.30. Then if the coin comes up heads, you get 30x4=120 from your investment, plus Rs. 20 left from your initial amount. So you will receive a total of Rs.140. However, if the coin comes up tails, you will get nothing from the 30 rupees that you invested. So in this situation you will only get Rs.20 left from the initial amount that you chose not to invest.

Do you have any questions? If you are ready, we will proceed.

We will call each of you one at a time in the adjoining areas where you will be asked a few questions and participate in the described task.

Once you have finished the task, you will go back to your sitting area. Please make sure that you do not converse with anyone. If we find you conversing you will be disqualified from further participation and escorted out by one of the experimenters. 


\section{Decision Sheet for the Investment Game}

Player ID \#:

Please complete the example below:

1. If you choose to invest Rs 15 and the coin toss comes up heads, what will you receive?

Rs

$\mathrm{X}$ $=\mathrm{Rs}$

Actual Decision:

2. Amount that I wish to invest:

3. Reason for this decision: 


\section{Instructions for the Competition Game Player ID \#:}

We are about to begin the next task. Please listen carefully to the instructions. All the money that you earn from this task is yours to keep and will be given to you at the end of this experiment if this task is chosen as the one that you will be paid for.

For this Task, you will be asked to fill bags with Rajma beans and seal it so its contents remain securely inside. We will give a demonstration before you start the task.

You will be given 1 minute to fill up as many bags as you can. Only bags filled and properly sealed will be counted towards your payments.

You can choose one of two payment options for this task.

\section{Option 1:}

If you choose this option, you get Re. 4 for each bag that you fill properly in 1 minute.

\section{Option 2:}

If you choose this option, you will be randomly paired with another person and your payment depends on your performance relative to that of the person that you are paired with. If you fill up more bags properly than the person you are paired with, you will receive Rs.16 per bag that you filled. If you both fill the same number of bags you will receive Rs. 16 per bag. If you fill up less number of bags than the person you are paired with, you will receive Rs. 0 .

Note that what you will earn does not depend on the decision of the person that you are paired with; it only depends on your own choice of payment, your performance and their performance.

Here are some examples of what could happen:

1) You choose option 1 . You fill 10 bags properly. You will receive 10xRe. $4=$ Rs. 40.

2) You choose option 2. You fill 3 bags properly. The person that you are paired with fills 2 bags properly. You will receive 3xRs.16 = Rs. 48.

3) You choose option 2. You fill 3 bags properly. The person that you are paired with fills 4 bags properly. You will receive 3 x $0=$ Rs. 0 .

Note that these are examples only. The actual decision is up to you.

The rest of the task will proceed as follows:

Next, we will call each of you one at a time in the adjoining area where you will be asked a few questions and choose your preferred option in the above described task. Once you have answered the questions and indicated your preferred option, you will come back to your sitting area. Please make sure that you do not converse with anyone at this time. If we find you conversing you will be disqualified from further participation and escorted out by one of the experimenters.

Once everyone is back to the seating area we will announce the start of the task and you can start filling up the bags. We will make an announcement when there are 30 seconds remaining. When time is up, we will say, "Stop the task now". You should immediately stop filling the bags. Please make sure that your hands are in your lap now and not 
touching any of the bags that you filled up. If you do not do this within 2 seconds, you will receive Rs. 0 for the entire experiment.

We will come around and inspect the bags and record the number of bags filled each of you managed to fill up.

Once all counting is done we will flip a coin to decide which of the two tasks will be chosen for payments.

After the coin toss, each of you will be again called one at a time to the adjoining area for the final payment procedures.

Are there any questions before we begin? If you are ready, we will proceed. 
Player ID \#:

Decision Sheet for the Competition Game

\section{Questions for Task \# 2}

Please answer the following questions:

1. Suppose you choose Option 1 . You complete 11 bags correctly at the end of 1 minute. How much money do you receive?

$\mathrm{x}$ Rs

$=$

2. Suppose you choose Option 2. You complete 7 bags correctly. The person you are paired with completes 6 bags correctly. How much money do you receive? $\mathrm{x}$ Rs $=$

3. How many bags do you think you can fill properly in 1 minute?

4. If we were to rank everyone's performance, in the group of people in this room, from best to worst, where do you think you would fall compared to the average person? Please place a tick next to the rank that you think applies to you.

— 1-4 (very above average)

_ 5-8 (above average)

_ 9-12 (average)

_13-16 (below average)

_ 17-20 (very below average)

5. We now ask you to choose how you want to be paid: according to option 1 or option 2?

6. What was your decision based on?

7. If you chose Option 1, did your decision depend on the payment rate undler Option 2 ? If so, what payment rate would have convinced you to choose Option 2? 


\section{Instructions for Final Payment Determination}

We will now determine what task to pay you for. We will flip a coin; you will all be paid for task 1 if Heads come and task 2 if Tails come up.

If Head comes up, then Task 1 is chosen: Each one of you will flip a coin to determine whether your investment succeeded or not. If the coin comes up heads, you win four times the amount you chose to invest. If it comes up tails, you lose the amount invested. If Tail comes up then Task 2 is chosen: We will pay you according to the choice you had indicated earlier.

If you had chosen option 1, we will pay you according to your performance.

If you had chosen option 2, we will ask you to pick one chit amongst several chits of paper on the front desk. Each chit contains an id number of one of the participants. Your performance will be matched with the performance of the participant whose ID number you picked. You will be paid according to your relative performance as described earlier.

Now we will call each of you one at a time like before. Please take your decision sheets with your ID\# written on it when you come. 


\section{Visual Charts}

Figure A1: Slides used in the Investment Game in conjunction with the oral instructions

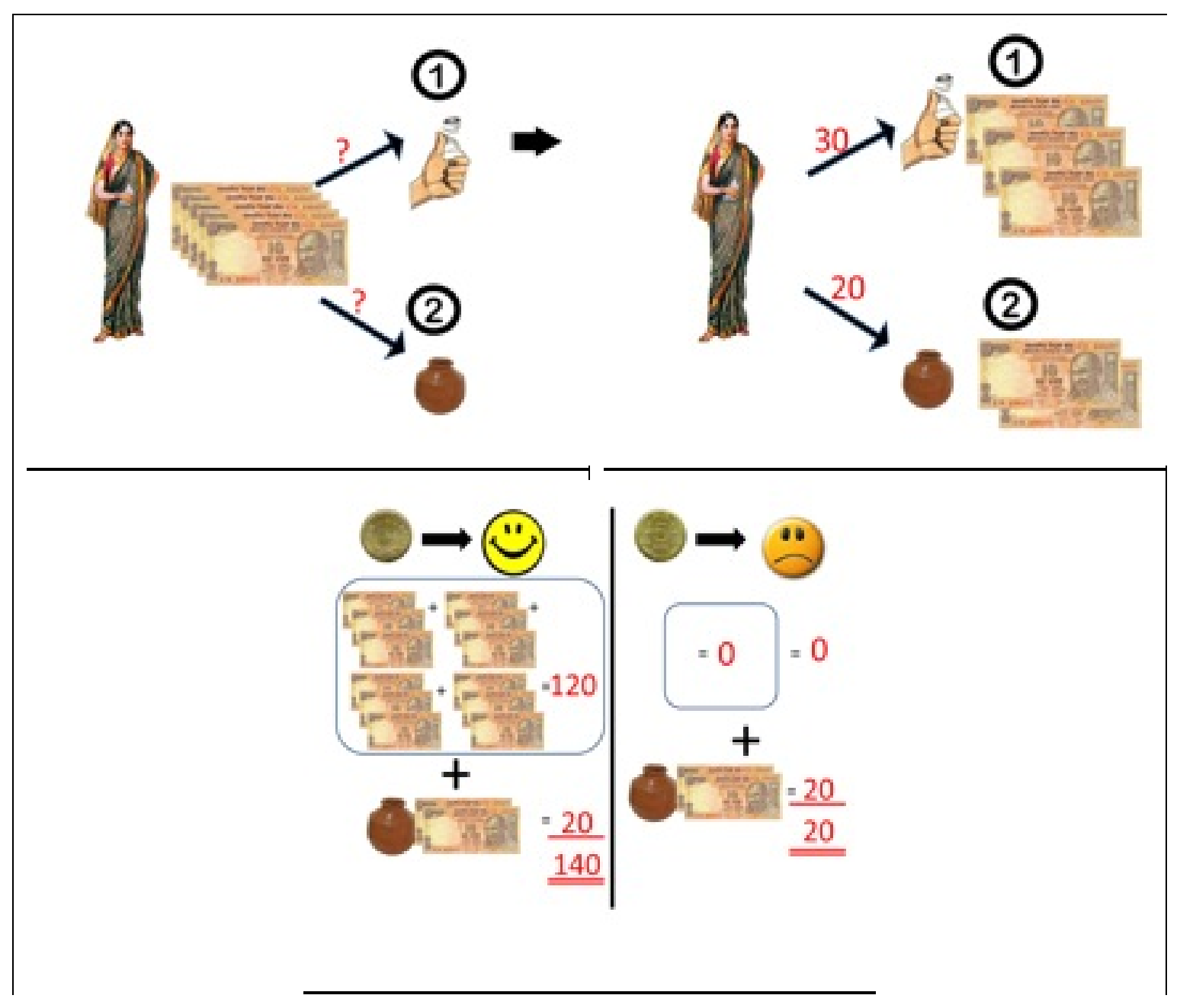


Figure A2: Visual slides used in the Competition Game in conjunction with the oral instructions

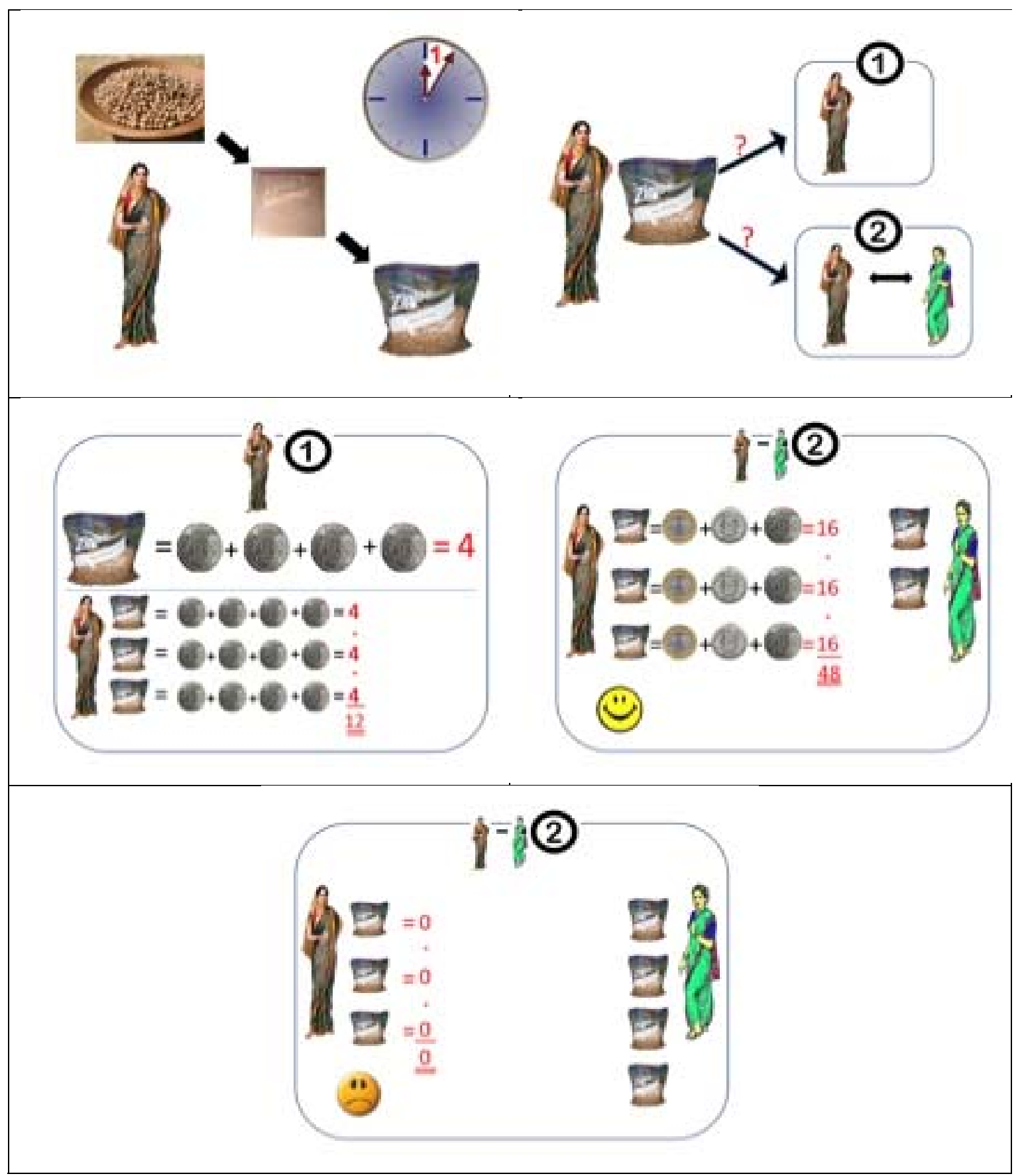

